\title{
PEAGEBUILDING IN FRAGILE CONTEXTS
}

\author{
Jonathan Marley
}

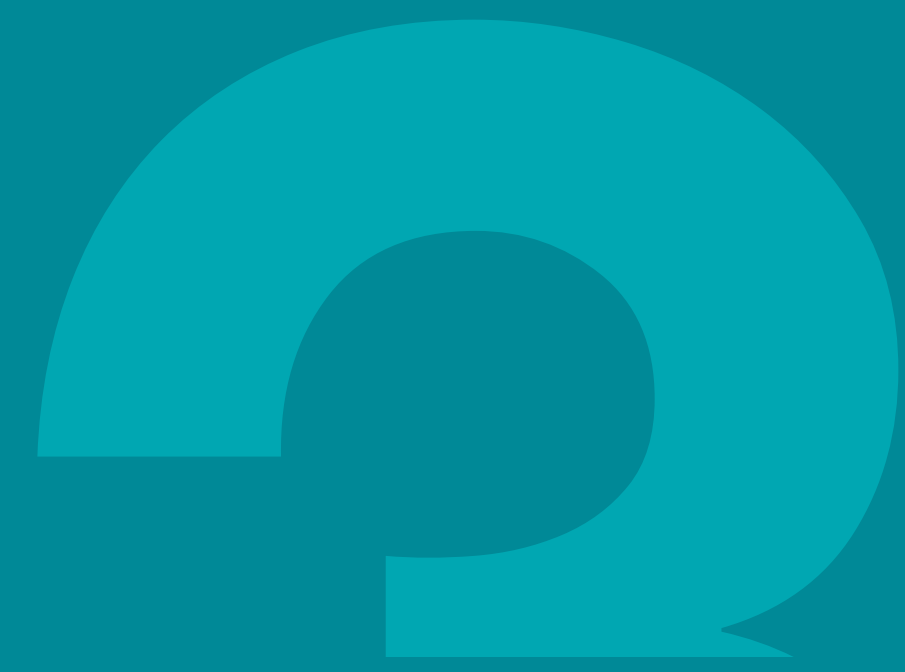

\section{OECD DEVELOPMENT CO-OPERATION WORKING PAPER 83}

Authorised for publication by Jorge Moreira da Silva, Director, Development Co-operation Directorate 



\section{OECD Working Papers}

OECD Working Papers do not represent the official views of the OECD or of its member countries. The opinions expressed and arguments employed are those of the authors.

Working Papers describe preliminary results or research in progress by the authors and are published to stimulate discussion on a broad range of issues on which the OECD works. Comments on the present Working Paper are welcomed and may be sent to dac.contact@oecd.org — the Development Co-operation Directorate, OECD, 2 rue André-Pascal, 75775 Paris Cedex 16, France.

Please cite this paper as Marley, $\mathrm{J}$, "Peacebuilding in Fragile Contexts", OECD Development Co-operation Working Papers, No 83, OECD Publishing, Paris. 


\section{Abstract}

Peacebuilding thinking and practice have evolved significantly over the past decade. The business case for the effectiveness of peacebuilding has been established. Successful interventions underscore the importance of peacebuilding initiatives, as do the high-profile failures that occur when peacebuilding is absent, fragmented or insufficient. With the emergence of new approaches to peacebuilding led by the United Nations Peacebuilding Architecture Review, this paper examines the state of peacebuilding operations and finance in fragile contexts and, building on established trends and debates, identifies four areas that could be critical for driving progress on peacebuilding over the next decade. The paper is one of ten working papers supporting States of Fragility 2020. Together with the papers entitled "Diplomacy and peace in fragile contexts", "Conflict prevention in fragile contexts", and "Security actors in fragile contexts", It provides a comprehensive background to Chapter 2 on peace in States of Fragility 2020. 


\section{Acknowledgements}

This working paper was authored by Jonathan Marley, Policy Analyst in the Crises and Fragility team of the Global Partnerships and Policy Division (GPP) in the Development Co-operation Directorate (DCD) of the OECD. The paper, which is a background document to States of Fragility 2020, was written under the supervision of Cyprien Fabre (Policy Analyst, GPP/DCD) and Paloma Durán y Lalaguna (Head of Division, GPP/DCD).

The author would like to thank Harsh Desai for supporting the development of Chapter 2 in this paper. Noting that all errors and omissions are his own, the author would also like to acknowledge the guidance, support and encouragement of Erik Forsberg, Kathleen Forichon, Cushla Thompson and Cyprien Fabre (OECD); Peter Batchelor \& Rachel Scott (UNDP); Sara Batmanglich (World Bank); Hugh Macleman (World Food Programme), Jago Salmon (SIPRI/Centre for International Cooperation), Tyler Beckelman (USIP) and all of the members of the States of Fragility 2020 reference group.

Thank you to Susan Sachs for her editorial support. 


\section{6}

\section{Table of contents}

Abstract 4

$\begin{array}{ll}\text { Acknowledgements } & 5\end{array}$

Executive summary $\quad 7$

1 Why is peacebuilding important for fragile contexts? 10

The state of peace in fragile contexts 10

Peacebuilding thinking and practice 12

Renewing the case for peacebuilding 18

Notes 19

2 Development Assistance Committee members' support for peacebuilding in fragile contexts 20

External support for peacebuilding: The roles of DAC members 20

Challenges to financing peacebuilding 25

Notes $\quad 26$

3 Four questions on empowering the peacebuilding agenda 27

Should donors prepare for a surge in demand for peacebuilding? $\quad 27$

How can the value of localised peacebuilding be consolidated? 28

How can the nexus work for more effective peacebuilding?

Is it time to develop a concept of digital peacebuilding?

Notes 32

Figures

Figure 2.1.Top 20 fragile recipients of peace ODA, 2018

Figure 2.2. Top 20 providers of peace ODA among all donors, $2018 \quad 21$

Figure 2.3. Peacebuilding expenditures to fragile contexts, 2012-18

Figure 2.4. Peacebuilding expenditure as a component of total ODA to fragile contexts, 2018

\section{Boxes}

Box 1.1. Zimbabwe: Fragility and peace $\quad 12$

Box 1.2. What is peacebuilding? $\quad 13$

Box 1.3. Political will and security sector reform $\quad 15$

Box 2.1. Non-DAC countries are prominent providers of ODA to fragile contexts 22 


\section{Executive summary}

This paper analyses the state of peacebuilding and peacebuilding finance in the 57 fragile contexts on the 2020 OECD fragility framework and considers four areas critical for empowering national and international peacebuilding priorities over the coming decade. It is presented as a background paper to the OECD report, States of Fragility 2020, with the goal of informing humanitarian, development and peace partners' support to fragile contexts. A companion working paper, "Conflict prevention in fragile contexts" (Desai, $\left.2020_{[1]}\right]$, focuses on the concept and application of conflict prevention in more detail.

Peacebuilders help ensure that peace is anchored in society through building trust and reconciliation. It is broadly accepted that they should be local actors supported where possible and appropriate by external actors. Through societal, geographic and economic networks, peacebuilders frequently encounter the localised aspects of fragility and coping capacities that other actors cannot reach and where they can address core issues - trust, reconciliation and compromise, among others - that affect the functioning of society and the state. Recognising and resourcing actors across the nexus in fragile contexts can help drive locally informed designed and owned solutions. This process is enabled by the collective understanding of the issues of fragility that shape the quality of peace in fragile contexts.

In Chapter 1, this paper explores why peacebuilding matters for fragile contexts, the progress made in terms of peacebuilding practice and the potential for further developments. The importance of the Development Assistance Committee (DAC) and non-DAC finance for peacebuilding is highlighted in Chapter 2, which notes the significant scope for more and better-aligned funding for peace. Acknowledging the focus of contemporary debates on peacebuilding, Chapter 3 identifies four alternative areas that will require attention if the collective ambitions for sustainable peace in fragile and conflict affected contexts are to be attained.

\section{Local ownership of peacebuilding processes in fragile contexts should be deepened at every opportunity}

The application of the concepts of local ownership and building social cohesion requires further development. Genuine local ownership of peacebuilding has proved difficult to establish. In practice, locals often are invited to implement peacebuilding models imported from outside. Trust building, reconciliation and local networks are essential to local ownership, providing the basis for accountability, credibility, legitimacy and local leadership that contribute in turn to the development of social cohesion. The OECD DAC Recommendation on the Humanitarian-Development-Peace Nexus can be adapted to ensure that these elements are harnessed for peace through multi-level partnerships. 


\section{Addressing the politics of local ownership is essential for the traction, momentum and sustainability of peacebuilding processes}

At all levels, the political will to engage in, support and make compromises for peacebuilding is essential for sustainable outcomes. In fragile contexts, peacebuilding agendas often compete with alternative processes, including conflict, in ways that reflect political actors' motives and decisions. In contexts where peace is compromised, the risk of political detachment or parallel governance structures can undermine peacebuilding. Engaging elites, diversifying awareness, increasing transparency, and exploring options for accountability and leadership can help build the political will necessary for resilient processes.

\section{Gaps between local and national peacebuilding processes must be bridged for more resilient outcomes}

The increased emphasis on localised approaches to peacebuilding has been one of the most positive developments in peacebuilding policy and practice. This focus on inclusivity and diversifying the basis for peace can be instrumental in building support for peace. Yet, many such initiatives dissipate over time due to inadequate resources, isolation from national processes or insufficient scale. Effective local ownership - critical to sustaining peace - cannot be sustained in the absence of an operational missing middle that can harness the potential of local initiatives for national and regional-level peacebuilding. For peace to emerge and consolidate, peacebuilding beyond localised initiatives is equally important. Bridging the gaps between local peacebuilding and national and higher-level processes can serve to maintain attention on the importance of local issues for peace while recognising that these frequently require political and institutional support to prosper over time.

\section{Aligning analysis of fragility with the OECD DAC Recommendation on the Humanitarian-Development-Peace Nexus can mobilise}

The importance of sufficient and flexible funding for peacebuilding is highlighted in the 2020-24 strategy of the United Nations (UN) Peacebuilding Fund and by a range of other actors. However, current funding patterns are at odds with the business cases that establish the cost-effectiveness of conflict prevention and peacebuilding. Implementation of the DAC Recommendation on the nexus, in parallel with recent initiatives such as the European Union's Whole of Society Conflict Prevention and Peacebuilding project and the findings of the UN Peacebuilding Architecture Review, can provide the starting point to mobilise greater investment in peacebuilding and conflict prevention to realise their cost benefits.

\section{The impact of more frequent climate change-related events, the coronavirus (COVID-19) pandemic and associated economic crises could drive unprecedented demand for peacebuilding support in fragile contexts}

Pressures relating to issues of fragility are growing in fragile contexts. The impact of three global systemic shocks that are causing trade and financial disruption, combined with significant increases in extreme poverty, violence against civilians and growing gender inequality, are straining already limited coping capacity in fragile contexts. In addition to focusing on local ownership, funding and social cohesion - all central to peacebuilding debates - all actors must also confront the real possibility that these global shocks may precipitate a significant increase in demand for peacebuilding support in fragile contexts. 
Peacebuilding practice must evolve to operate more effectively in the digital space

As the technology and application of social media platforms evolve, and with connectivity to the Internet and mobile technology expanding in fragile contexts, social media campaigns are increasingly affecting peacebuilding processes. In a contested digital space, where many actors are capable of reaching large audiences, peacebuilders must communicate the authenticity of peacebuilding motives and ensure that social cohesion and local ownership continually inform their digital interactions. 


\section{Why is peacebuilding important for fragile contexts?}

Peacebuilding activities address core issues that affect the functioning of society and the state before, during and after conflict. Depending on the context, peacebuilding can overlap significantly with conflict prevention measures and can encompass a wide variety of actors, institutions and organisations everyone from anthropologists and village councils to civil society organisations (CSOs) and heads of state may be involved. These peacebuilding actors can often address aspects of fragility that development, diplomatic and security actors across the nexus (with the general exception of humanitarians) cannot reach due to political, societal, security or geographic factors. While the actions of humanitarian, development and security actors tend to focus on their specific areas of competence, it is important to acknowledge that these actors can also contribute significantly to peacebuilding processes. Recognising peacebuilding capacity in fragile contexts and resourcing it effectively can help drive locally informed and owned solutions to fragility, thereby sustaining peace. A sound analysis of the multidimensional risks and coping capacities to the fragility in fragile contexts can unlock the potential of peacebuilding (Desai, 2020[1]).

The last decade has witnessed a significant evolution in peacebuilding thinking and conduct. Concepts of peacebuilding have evolved to include programmes and tools to address political, developmental, humanitarian, societal and human rights issues at a variety of levels in fragile contexts. With the advent of the United Nation (UN) Peacebuilding Fund, thinking of finance for peacebuilding has also evolved though much work remains. This paper, one of four background papers to the OECD States of Fragility 2020 report focused on fragility and peace, ${ }^{1}$ examines the state of peacebuilding and peacebuilding finance in fragile contexts (Chapters 1 and 2). Complementing contemporary debates, it concludes in Chapter 3 with an alternative look at the main focus points of peacebuilding debates and identifies four areas for immediate and focused attention by members of the OECD Development Assistance Committee (DAC) to enable effective action on the dominant themes in peacebuilding discourse. In contexts where fragility is most evident, peace is most vulnerable. This chapter examines in detail why peacebuilding is important for fragile contexts.

\section{The state of peace in fragile contexts}

The 2020 OECD fragility framework identifies 57 fragile contexts, 13 of which are classified as extremely fragile and the remaining 44 as fragile (OECD, 2020[2] ). From 2010 to 2019, the number of active violent conflicts in fragile contexts increased by $128 \%$. Violent conflict and its consequences are now more concentrated in fragile contexts than ever before (Pettersson and Öberg, 2020[3]). Fragile contexts account for $76 \%$ of all active state-based violent conflicts and $96 \%$ of all battle-related deaths from armed conflict in 2019 (UCDP, 2020[4]). The three major armed conflicts identified by the Stockholm International Peace Research Institute in 2019 were in Afghanistan, the Syrian Arab Republic (Syria) and Yemen, all extremely fragile contexts (SIPRI, 2020 $[5]$ ). The demand for effective conflict prevention and peacebuilding is rising.

The interplay between causes and types of violence is highly complex and closely entangled with the exercise of politics and power. When violence and conflict are used as a means to advance political 
objectives, the damage to people, societies, institutions and environments can be shocking and longlasting. Compounding this physical and psychological trauma is that those engaged - driven by a sense of grievance and/or the pursuit of power - often choose to expose and target fragility in opposing peoples, communities, institutions and states. The economic issues of fragility that may give rise to conflict take on new meaning during conflict. Conflict economies can bring official state, non-state and criminal organisations together in relationships of convenience and often self-interest. These undermine the integrity of economic systems in fragile contexts and erode the basis for recovery. Local and national economic motivations distorted by conflict can "play a critical role in the persistence of open fighting, localized violence and coercion" (Eaton et al., 2019, p. iv $\left[\mathrm{v}_{[6]}\right)$.

The common practice of arbitrary justice in conflict can also erode the future basis for trust, greatly complicating the pathways to peace. Arbitrary justice, the targeting of vulnerable groups and particularly women, and the instrumentalisation of forced displacement for conflict goals cynically target social cohesion. For example, armed groups seeking to leverage economic, societal, political and security advantage often pursue a strategy of forcibly displacing people, with the goal of pressuring displaced populations and host communities to influence bargaining "between governments and opposition actors along social, religious and political lines" (International Institute for Strategic Studies, 2019[7]). The application of force to displace populations is also used to "provide cover for militants and their arms to enter new territories and cross international boundaries, placing host communities at risk of conflict diffusion" (International Institute for Strategic Studies, 2019 $\left.{ }_{[7]}\right)$. Multidimensional analysis for peace must therefore balance consideration of the root causes of fragility that give rise to conflict, on one hand, and the manipulation and aggravation of issues of fragility to sustain conflict, including by external actors, on the other. This poses a series of policy dilemmas for actors across the humanitarian-development-peace nexus, where the "aspiration to 'do no harm'" meets the reality of calculating policy and operational risks in highly complex environments that are frequently conducive to "unforeseen and/or negative consequences" (Eaton et al., 2019, p. v[6]).

This paper does not focus on the specific importance of conflict prevention for building peace, as it is addressed by Desai $\left(2020_{[1]}\right)$, but instead seeks to complement the arguments developed in that companion paper by applying a broader framework for peacebuilding analysis. Even in the absence of violent conflict, analysis of issues of fragility - understood as "exposure to risk and insufficient coping capacity of the state, system, and/or communities to manage, absorb, and mitigate those risks" ${ }^{2}$ - offers insight on the potential for negative or positive peacebuilding in fragile contexts, where negative peace is understood as the absence of violence and positive peace is associated with structural resilience and social justice (Galtung, 1969 ${ }_{[8]}$ ).

\section{The potential for violent conflict in fragile conflicts is rising}

The potential for violent conflict in fragile contexts that are not affected by conflict is growing. Issues such as inequality, poverty, injustice, corruption and weak governance can combine in ways that give rise to incidents of violence and sustained conflict. Effectively addressing these issues is essential for building and sustaining peace. This holds true across the spectrum of violent actions that can, in different ways, undermine the social and political fabric of a fragile context, from domestic, gender-based violence to armed criminality and intrastate and inter-state conflict. While war and high-intensity conflict tend to garner the headlines, instances of conflict are comparatively lower than in previous eras. Data on different types of civil unrest reveal a more nuanced and concerning picture for the future. Protests in fragile contexts increased by almost 48\% between Q1 2018 and Q4 2019 (ACLED, 2020[9]). Incidents of civil unrest in subSaharan Africa rose by more than $800 \%$ in eight years, increasing from 32 riots and protests in 2011 to 292 in 2018 (Institute for Economics and Peace, 2020, p. $4_{[10]}$ ). While such events can be politically instigated, to some degree they usually arise from grievance associated with issues of fragility. 
The duration of severe fragility is a significant factor for the resilience of peace. Since the OECD established the fragility framework, 21 contexts have emerged as chronically fragile in that they also appear in every OECD fragility report since $2005 .^{3}$ Of these, eight have not experienced an active, state-based conflict since 2009, whereas 16 of the 21 have not experienced a high-intensity, state-based conflict (Pettersson and Öberg, 2020[3]). For conflict-affected contexts such as Afghanistan, fragility is intimately associated with the full range of inter-state, intrastate, non-state and one-sided categories of organised violence (UCDP, 2020[11] ). In these, the primary challenge is to restore peace. The focus in fragile contexts not affected by conflict should be somewhere between prevention and sustaining peace. Chronically fragile contexts are diverse, with different elements affecting their specific character and level of fragility, as the example of Zimbabwe in Box 1.1 illustrates. Analysis across dimensions of fragility reveals a range of areas of relevance for peacebuilding activity, most notably around inequalities, climate-related issues and, more recently, the impact of coronavirus (COVID-19), which in many contexts has deepened the fissures of fragility that can compromise peace.

\section{Box 1.1. Zimbabwe: Fragility and peace}

Zimbabwe is experiencing a notable deterioration across dimensions of fragility that points to its increasingly fragile peace. It exhibits moderate to severe fragility across all dimensions in the OECD 2020 fragility framework. The triple impact of natural disasters, most recently severe drought, alongside economic crisis and the health and socio-economic impact of COVID-19 has pushed the country deeper into fragility.

The intersections of fragility in Zimbabwe indicate pressure points for sustaining peace. The World Bank $\left(2020_{[12]}\right)$ estimated that $40 \%$ of Zimbabwe's population was experiencing extreme poverty and $50 \%$ were food insecure in 2019. Inflation surged to $521 \%$ year-on-year by December 2019, and food prices increased by $725 \%$ resulting in a severe loss of purchasing power for most households even before the pandemic (World Bank, 2020[12]).

The socio-economic impact of COVID-19 has been significant and coincides with a notable increase in violence against civilians (ACLED, 2020[9]) This is largely attributable to a severe police crackdown on public gatherings (Mukeredzi, 2020[13]), including the targeting of anti-corruption protesters and the arrest and detention of journalists and opposition political leaders (Human Rights Watch, 2020[14]). Zimbabwe is severely fragile in the political dimension of the fragility framework, and voice and accountability and perceptions of corruption stand out as notably weak. Hopes for reform the security sector following the transition to the Mnangagwa administration have dissipated and sanctions remain

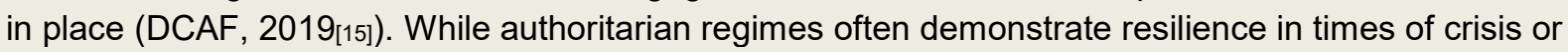
disaster, when they collapse, the unravelling can be swift and devastating. The situation in Zimbabwe is delicately poised and needs to be monitored closely from a peacebuilding perspective.

Note: More information is available in the Zimbabwe country profile on the States of Fragility platform at http://www3.compareyourcountry.org/states-of-fragility/overview/0/.

\section{Peacebuilding thinking and practice}

Thinking on peacebuilding has evolved considerably over the past decade. With increasing recognition of the UN's concept of a continuum of sustaining peace (Advisory Group of Experts, $2015_{[16]}$ ), peacebuilding is understood less and less as a post-conflict activity, though the African Union policy on peacebuilding still predominantly focuses on this aspect (African Union, 2018 ${ }_{[17]}$ ). In spite of the elasticity of the term peacebuilding (Box 1.2), there appears to be a strong consensus on core components of the concept, 
including on the importance of local ownership and inclusivity, conflict sensitivity, analysis of root causes, and capacity building and building trust. This section focuses on two challenges associated with these components: those associated with the substance and application of local ownership and the difficulties posed by fragmented approaches to building peace.

\section{Box 1.2. What is peacebuilding?}

Often used interchangeably with conflict prevention (which tends to focus more often on the threat or use of armed force and other forms of violence), peacebuilding is a term that is understood in many different ways.

The UN refers to peacebuilding as activities aimed at reducing "the risk of lapsing or relapsing into conflict by strengthening national capacities at all levels for conflict management and to lay the foundation for sustainable peace and development. It is a complex, long-term process of creating the necessary conditions for sustainable peace. Peacebuilding measures address core issues that affect the functioning of society and the State and seek to enhance the capacity of the State to effectively and legitimately carry out its core functions" (UN, 2020[18]).

Echoing the 2015 Peacebuilding Architecture Review, the United Nations Secretary-General has emphasised the importance of building and sustaining peace not only once conflict has broken out, "but long beforehand through preventing conflict and addressing its root causes" (UN, 2018[19]). Other presentations of peacebuilding highlight the diversity of actors. For instance, the Alliance for Peacebuilding (n.d.[20]) highlights the inclusion of "government and civil society at the community, national, and international levels", and the importance of supporting "human security - where people have freedom from fear, freedom from want, and freedom from humiliation". It also emphasises two broad meanings of peacebuilding - as a direct process focusing on factors driving and mitigating conflict and as an "integral comprehensive set of interrelated efforts that support peace, including economic development, humanitarian assistance, governance, security [and] justice" (Alliance for Peacebuilding, n.d. $[20]$ ). The latter understanding speaks to the potential of working across the humanitariandevelopment-peace nexus where all actors can influence peace through formal and informal means (OECD, 2020[2]).

\section{The local ownership dilemma: Trusting politics}

The local ownership of peacebuilding processes is broadly accepted as the best way to achieve effective outcomes. However, the application of local ownership varies significantly and has proven difficult to establish in practice. External actors supporting peacebuilding often find it difficult to identify local stakeholders, local participation can be inconsistent, and the concept and process of conflict prevention and peacebuilding initiatives can themselves be a source of tensions as external and local actors compete to address the needs and political aspirations of their respective communities (Bojicic-Dzelilovic and Martin, 2016, p. $7_{[21]}$. The quality of local ownership is also an issue. While programmatic emphasis is often placed on local ownership and leadership, analysis has shown that crucial local input and knowledge are often absent at the planning and design stage, culminating in what Collins and Thiessen (2019[22]) describe as "shallow ownership", where local actors are encouraged to "buy into externally designed reform strategies" rather than more inclusive and self-determined versions of ownership and implementation. This, in turn, can also feed into the commonly identified issue of a lack of political will for peacebuilding.

Generating and supporting political will for a peacebuilding process is a highly complex exercise, and external actors are often reluctant to engage in local political conversations (Box 1.3). However, at local and national levels, political parties are frequently central to building, sustaining and also undermining peace. Factors ranging from their experience of violence and conflict to the nature of the political system 
they exist within can shape their behaviour and decision-making (Castillejo, 2016[23]). An additional factor can be the relative power they exercise with that political system. For example, political leaders who form parts of what Travers (2015, p. 3[24]) called "entrenched elites" are almost always highly sensitive to external initiatives. If not managed appropriately, this tendency can have the counterproductive impact of causing groups to resist the aims of a peacebuilding process and seek to protect their power through the means at their disposal such as "undermining electoral processes, weakening human rights institutions, limiting space for political opposition, or curbing freedom of the press" (Travers, 2015, p. 3[24]). While such dynamics make peacebuilding extremely difficult, they do not make it impossible. Depending on the context and the political personalities, peacebuilding processes can be stimulated by the astute appointment of external political interlocutors (such as former United States Senator George Mitchell as special envoy for Northern Ireland) who can operate above the technicalities of peacebuilding processes to engage local politicians on a peer-to-peer basis (Forsberg and Marley, 2020[25]).

Other research (on elite bargaining) has noted that awareness of changes in the socio-economic fabric of a fragile context can alter the terms upon which the political will for peace negotiations is developed (Cheng, Goodhand and Meehan, 2018, p. 20[26]). Sustaining the recent emphasis on building closer working relationships with civil society organisations offers the double benefit of building local capacity for peacebuilding while also enhancing knowledge of local dynamics. However, it should be noted that depending on the context and the organisation, interacting with civil society organisations could also carry political risk for all participants. Analysing the political-economic attributes of a fragile context can also be instructive for understanding positions taken by actors (formal and informal) in a peacebuilding process particularly where the economic opportunities created by conflict can prove more attractive when contrasted with "civilian, legal economic behaviour" (Rotmann, 2019[27]). Political economies in fragile and conflict-affected contexts can present in a number of ways from overt attempts to sustain conflict economies to the more subtle actions of elites controlling state institutions for personal gain. Depending on the context, this can impact significantly on political will for security sector reform in a given context (Box 1.3).

The extent to which accountability to local actors is part of an external contribution to peacebuilding processes also matters. As highlighted by Campbell (2018, p. $48_{[28]}$ ), peacebuilding dynamics between external and local actors are often compromised when "local stakeholders are not authorised to hold global actors accountable for achieving their local level aims". A decision to build local accountability by ensuring local actors' authority over the design, direction and content of peacebuilding activities can also build trust and serve to empower and incentivise local political actors to take more visible roles in the process. Finally, it is important to recognise that political will for peacebuilding is not something that is reserved only for the high politics of peace negotiations and agreements. It matters, too, at the sectoral levels of peacebuilding practice, from the implementation of development policy to government reform. 


\section{Box 1.3. Political will and security sector reform}

Security sector reform (SSR) is frequently seen as a core component of peacebuilding in fragile contexts. In considering the civilian oversight and support for SSR in executive-legislative relationships in West Africa, political will was identified as the single most important condition for ensuring that legislatures perform their oversight function effectively (Pelizzo and Stapenhurst, 2014, p. 256[29]). Developing, maintaining and reinforcing political dialogue is viewed as an essential part of security sector reform processes (DCAF, 2020[30]). However, in practice, it has proven to be one of the most common stumbling blocks.

Appreciating the substance of and potential for political will for change in a fragile context is a highly complex task. Understanding the motives of actors engaged in peacebuilding processes is a significant determinant of their willingness to support or hinder a process that may be shaped by, among others, military, police, external interference or elite dominance. A variety of factors can influence the motivations of each of these groups: the salience of the reform proposed for their sectoral interests, whether they have their concept of reform, the relative balance of power among stakeholders, and the cultural and identity aspects of the political landscape (Hammergreen, 1998, p. 13[31]). The mandates and capacities for peacebuilding also influence the short- and long-term calculations and strategies of peacebuilding participants. Depending on the context, political will can be closely associated with public support. Expanding the conceptual basis for political engagement can help reform processes navigate chokepoints by spreading political dialogue across "a mixture of elite commitment (political will), organized lobbies (constituencies), and public support" (Hammergreen, 1998, p. 11 [31]).

The incentives for change must account for actors' expectations for the benefits of reform and are therefore critical for the development and implementation of SSR processes. In cases where the incentives to reform appear to lack purchase, it may be necessary to first rethink whether sufficient demand exists for reform among political elites and whether the capacity exists to create sufficient will and then consider the potential resilience of a reform process as the political landscape evolves (Hammergreen, 1998, p. 16 $6_{[31]}$ ). The latter is significant for SSR (and peacebuilding), as both tend to be long-term, generational processes). In Burundi, for example, the pace of security sector reform proved insufficient to withstand the changes to the political landscape brought about by former President Nkurunziza's unwillingness to step down following his second term in office in 2015. The subsequent implications for the security sector have been significant. It had been one of the most effective examples of security sector reform on the continent (Ball, 2014[32]), but moved to a situation of "defections and titfor-tat violence in the military, targeted killings of civilians - often with ethnic undertones - and the launching of armed rebellions by three separate movements" (Nantulya, 2019 $9_{[33]}$ ). The governing CNDD-FDD party also restructured executive oversight of the security sector to afford it greater control over the military (Nantulya, 2019[33]).

These events are all the more sombre when one reflects on the findings of a review of SSR in Burundi conducted in 2014. It found, among other issues, that national ownership was too narrowly focused on the government, that there was a lack of commitment from the political authorities, and that "achievements will not be sustained unless there is a high level of commitment" (Hendrickson, 2014[34]). That concern proved to be well-founded. Within a year of the publication of the review, the SSR process effectively collapsed. 


\section{Fragmented peace: The rise and some shortfalls of localised approaches}

Communities, governments, civil society organisations, businesses, and external multilateral and bilateral actors have an important peacebuilding role. This is well known, as is the reality that the interplay of these actors and their interests create dynamics that often take processes away from the communities that are most vulnerable when peace deteriorates. The increased emphasis on localised approaches to peacebuilding has been one of the most positive developments in peacebuilding policy and practice. Built on the truism that "stability created by outsiders, however welcome in the short term, lacks both the mettle and resilience of a peace forged in the crucible of local dynamics and compromises" (Vernon, 2019, p. $3_{[35]}$ ), the localisation agenda has done much to refocus and legitimise peacebuilding attention where it matters most - on the initiatives designed, owned and led by people in and for their own communities.

The conversation on localisation tends to be (as it is in this paper) led by international organisations keen to learn from the successes and failures of peacebuilding endeavours. Critiques by external and international actors' contributions to local peacebuilding have identified a number of shortfalls, among them an implicit bias towards "formal, short-term, output-oriented programming" and a preference for supporting organisations "they already know" (Vernon, $\left.2019_{[35]}\right)$, as well as gaps in analysis on the aspects of fragility that drive risks to peace.

Yet evidence has emerged of effective support for local peacebuilding processes, including through the UN Peacebuilding Commission and Peacebuilding Fund and regional organisations such as the African Union, and the European Union's Whole of Society Conflict Prevention and Peacebuilding project. For example, evaluations find that establishment of peace committees has been effective in the South Kordofan province of Sudan, where they contributed to the successful resolutions of "many conflicts between farmers and herders, where the latter's animals were damaging vital crops" (Vernon, 2019[35]). The success of such initiatives is noteworthy when considered alongside the significant number of border and land-based disputes around herding and agricultural rights. These peacebuilding initiatives are also instructive as to how trust and legitimacy can be fostered within communities at local levels; for example, in the South Kordofan case study example, it was noted that "in $80 \%$ of interventions where violence had occurred and been brought to an end, no further violence was reported" (Vernon, 2019 [35]). Similar approaches also have been found to be effective in Sierra Leone and other countries. In the Democratic Republic of the Congo (Congo), for instance, a "cluster of peace structures known as baraza (Swahili for council) resolved at least 1,500 local disputes in three years" (Vernon, 2019[35]). In Niger, 356 Dimitra Clubs were established to enhance community-based participation and dialogue between village groups and local authorities, including the participation of 6030 women in an initiative that benefited 60 villages (UN Peacebuilding Fund, 2019[36]).

Recent local peacebuilding practices have also been noteworthy for their emphasis on inclusion and diversity. For example, the Kumekucha initiative of the Green String Network in Kenya sought to build community resilience by working to reduce "the risk of young people being recruited by violent extremist groups" (Vernon, 2019 ${ }_{[35]}$ ). Significant emphasis also has been placed on the role of women in community governance through support of their participation in a variety of traditional and where possible nontraditional roles. An initiative in the Central African Republic supported the participation of women in political processes by increasing their ability to access local capacity through advocacy training, including by identifying "the obstacles to more tangible political participation of women and to collect women's alternative proposals to facilitate their contributions" (UN Peacebuilding Fund, 2018[37]).

Bespoke support for civil society is also increasingly prevalent, including in extremely fragile contexts such as Syria and Afghanistan. Analysis of civil society during the conflict in Syria shows the complexity facing peacebuilders. It was difficult to disentangle the distinctions between CSOs and political movements, and binary narratives that tended to label "civil society as either 'close to the government' or 'close to the opposition'" proved both frustrating and unhelpful for actors involved (Hellmüller and Zahar, 2019, p. 85[38]). In part, as a result, CSOs struggled to establish a place in high-level initiatives to mediate peace such as 
those led by Kofi Annan, the UN-Arab League Joint Special Envoy for the Syrian crisis, and Lakhdar Brahimi, his successor in the post. The next special envoy, Staffan De Mistura, sought to institutionalise the participation of civil society by establishing the Civil Society Support Room as part of the Genevabased peace talks. Over time, this developed as a platform for local dialogue among CSOs that informed more conflict-sensitive proposals for issues such as transitional justice and elections based on recognition of local needs and priorities (Hellmüller and Zahar, 2019, p. 86 ${ }_{[38]}$ ). CSO inclusion "cannot substitute for a process in disarray" (Semple, 2019, p. 87[39]). Nevertheless, the Syrian example demonstrates how civil society organisations' nuanced local knowledge and perspectives can feed into even the most fraught and contested processes. It also underscores the importance of ensuring that peacebuilding processes (particularly higher-level processes) do not move beyond the influence of the local communities most affected by conflict, including in instances (such as in Afghanistan) where political configurations are prioritised over consensus building at local levels (Semple, 2019, p. 96 $6_{[39]}$ ). While the potential of local peacebuilding approaches is increasingly well established, it is important to note that local practice is subject to many of the same human and systemic flaws that affect other styles of engagement. The ethical and operational challenges identified for localised approaches in the humanitarian sector are also present in peacebuilding contexts, where "different interests, values, conflicts, exclusion and bias within communities themselves" (Slim, 2020[40]) can combine with local politics to impact on processes. Local awareness of national and regional dynamics, or lack thereof, can inadvertently shape decision making, as an increased access to social media platforms (Chapter 3). Local initiatives for peace are just as timesensitive as higher-level processes, and they require similar investment in gradual, incremental and conflict-sensitive approaches and the steady development of individual and collective trust, legitimacy and accountability.

While an emphasis on bottom-up approaches is important, the success of local initiatives is often relatively modest in the context of wider peacebuilding processes. Working across the nexus can yield significant benefits. Humanitarian, development and peace actors, through dialogue and joined-up planning, can identify the connections between issues of fragility and factors affecting peace. This approach can also encourage peacebuilding responses that are similarly informed and connected in their application. Just as top-down processes are seen as suboptimal in the absence of a local application, localised approaches can lose momentum if they are not connected to the national-level processes that can add layers of resilience. For this reason, the underlying principles of peacebuilding should be neither top-down nor bottom-up. Whenever possible, both approaches should be working in a complementary fashion.

Fragmentation is also an issue for external actors engaged in peacebuilding processes, most notable fragmentation between the different pillars of humanitarian, development and peace engagement in fragile contexts. Depending on the context and the specific competencies of a given external actor, different approaches can be applied to bridge fragmentation among localised peacebuilding initiatives. For example, diplomatic actors operating in fragile contexts have unique mobility to engage with actors across the triple nexus (Forsberg and Marley, 2020[25]), and they often have the means to combine legal authority, legitimacy and power of influence so that they can assume convening or facilitating roles that link local, national and international peacebuilding actors. New thinking on country platforms as strategic entry points in fragile contexts, as noted by Graff and Bailey $\left(2020_{[41]}\right)$, also shows how effective co-ordination by multiple actors can reduce fragmentation and ensure a better balance of local, national and external voices. It is recognised that country platforms need to evolve to capture the risk and resilience factors in a given context (Papoulidis, 2020[42]). Building conflict prevention and peacebuilding priorities into a platform's way of working could serve to bind humanitarian, development and security activities around agreed peace objectives. For many fragile contexts, this is not without significant challenges: platforms and other coordinating mechanisms still tend to be associated with specific pillars of engagement. The difficulties of navigating complex political economies and developing and sustaining political will for effective coordination also require adapting the concept to the specific needs of a context. However, where country platforms or similar co-ordinating mechanisms are applied, drawing on the concepts of social cohesion, 
inclusivity and meaningful local ownership, local actors must be vested with the authority and power of influence over platform design and operation to ensure legitimacy, credibility and sustainability.

\section{Renewing the case for peacebuilding}

The UN Peacebuilding Architecture Review will offer an appropriate moment for the wider peacebuilding community to reflect on and renew its contributions to peace. Since the last review in 2015 , the UN Peacebuilding Commission has noted a significant increase in demand for peacebuilding support (UN, 2020 , p. $4_{[43]}$ ). Most of that demand comes from fragile contexts. Fully 20 of the 23 countries that the UN Secretary-General declared eligible for the Peacebuilding Fund are fragile contexts on the OECD fragility framework (UN, 2019[44]). The 2020-24 strategy for the Peacebuilding Fund notes that significant questions remain around peacebuilding finance, given that demand for peacebuilding finance has outpaced supply and there is a call for more flexible funding for local organisations (UN, 2020, p. 10[43]). The potential for more flexible funding is significant. Not only can flexible funding broaden the base for local ownership. By adapting funding modalities, grassroots organisations that typically would not receive funding will have the opportunity to collaborate with established state institutions and international organisations. This can build dialogue and strengthen networks for sustainable peace. As UN peacekeeping operations such as MONUSCO are expected to wind down in the coming years, this type of policy approach can also be applied to peacebuilding aspects of transitions (OECD, 2020[45]).

\section{Pathways to coherence, inclusive and adaptive peacebuilding}

The intersections between fragility and peace in fragile contexts deserve closer attention in peacebuilding analysis and for the application of policy across the triple nexus. In the words of a UN official interviewed ${ }^{4}$ for this paper, "The absence or presence of peace is an importance factor shaping fragility and issues of fragility are important determinants of peace." The OECD States of Fragility 2020 report argues that when it comes to conflict prevention and peacebuilding, everyone has a role to play (OECD, 2020[2]). Two focus points related to this perspective are worth highlighting for their potential: social cohesion and adaptive peacebuilding.

The United Nations Development Programme (UNDP), in a recent report, defines social cohesion as "the extent of trust in government and within society and the willingness to participate collectively toward a shared vision of sustainable peace and common development goals" (UNDP, 2020, p. $7_{[46]}$ ). Related to this concept is the question of the extent to which participation can be enabled and how, in its application, social cohesion can support local ownership. The concept of social cohesion is already being applied in many peacebuilding initiatives. One example is the UNDP's engagement in the Solomon Islands, where 7 out of 10 people are under the age of 35 . Recognising this age demographic, the UNDP is working to establish youth caucuses as platforms for youth engagement in peacebuilding and nation-building processes. The rationale is that empowering youth in fragile areas to help create solutions to local issues and developing an inclusive decision-making culture can help sustain peace (UN Peacebuilding, 2018, pp. 10-11 [47]). While acknowledging it was too early to assess outcomes, a progress report midway through the project's implementation noted it had succeeded in engaging youth who previously existed on the "margin of society" (UN Peacebuilding, 2019, p. $4_{[48]}$ ).

Such initiatives point to the potential of social coherence. They also underline baseline enablers of peace that often go unnoticed in peacebuilding processes, particularly those associated with human capital. Given the long duration of peace processes, attending to human capital priorities could serve to empower approaches to promoting social cohesion and building social contracts. It would be worthwhile to further explore and invest in developing the peacebuilding potential of aligning investment in human capital with support for social cohesion. One area where there is arguably scope to pursue this approach is education, considering that education received only $8 \%$ of DAC members' official development assistance to fragile 
contexts in 2018 (Desai, 2020[49]). Such an approach not only would allow for broadening the base for incentives (de Coning and Gelot, 2020[50]), but might also be consistent with recent efforts to place people at the centre of peacebuilding processes by focusing on the issues of fragility and building resilience that matter most within their locality. The development of a human capital dimension in the OECD multidimensional framework for analysing root causes and coping capacities in fragile contexts may aid additional research and policy development in this area.

Investing in fragility analysis for building social cohesion could also complement concepts such as adaptive peacebuilding that seek to facilitate iterative processes of learning and adaptation by peacebuilders, communities and people affected by conflict in a "structured effort to sustain peace" that focuses on process and local resilience over pre-determined end-states (de Coning, 2018, p. 317 $[51]$ ). The evolutionary aspect of the adaptive peacebuilding approach would also appear to be well suited to responding to subtleties and nuances of supporting social cohesion. This will challenge monitoring and evaluation experts to develop programmes that can adapt more readily in evolving, complex systems. However, an appropriate balance should be sought that stops short of interference in local social processes "with the goal of engineering specific outcomes, such as trying to produce a neo-liberal state" (de Coning, 2013 ${ }_{[52]}$ ).

\section{Notes}

1 The other three background papers are "Conflict prevention in fragile contexts" by Desai $\left(2020_{[1]}\right)$; "Security actors in fragile contexts" by Forsberg (2020[64]); and "Diplomacy and peace in fragile contexts" by Forsberg and Marley $\left(2020_{[25]}\right)$.

${ }^{2}$ This understanding is included in the two most recent editions of the States of Fragility series, in 2016 $\left(\mathrm{OECD}_{[110]}\right)$ and in $2018\left(\mathrm{OECD}_{[61]}\right)$.

${ }^{3}$ States of Fragility 2018 identified 27 chronically fragile contexts by comparing lists over the ten-year period of 2008-18. The total presented in this paper considers the full time series since 2005.

${ }^{4}$ The statement is from a UN official interviewed by the author on 24 June 2020. 


\section{Development Assistance Committee members' support for peacebuilding in fragile contexts}

External support for peacebuilding and conflict prevention takes a variety of forms. Bilateral and multilateral diplomatic actors, humanitarian actors, development agencies, peacebuilding specialists and security actors all inform, shape and participate in aspects of peace processes from prevention to reconstruction. Alongside the issue of the fragmented nature of the activities carried out by these actors, a lack of sufficient, predictable and flexible funding is frequently identified as one of the primary challenges facing contemporary peacebuilding (UN, 2020[43]; UN, 2020[53]). The OECD Creditor Reporting System (CRS) and the total official support for sustainable development (TOSSD) tools suggest that the peacebuilding funding landscape is only slowly evolving. DAC members' official development assistance (ODA) for conflict prevention and peacebuilding is increasing, but from a very low baseline and at an insufficient level to meet current global demands for peacebuilding support. New ideas on innovative partnerships and adaptive approaches to peace would appear to fit well with the potential of the OECD DAC Recommendation on the Humanitarian-Development-Peace Nexus, especially given that current global crises may precipitate unprecedented demand for peacebuilding support. This chapter provides a short overview of the current levels of ODA for peacebuilding and the impact of non-DAC funding for peacebuilding and considers the potential for new thinking on peacebuilding finance that can emerge from nexus-informed approaches in fragile contexts.

\section{External support for peacebuilding: The roles of DAC members}

\section{Primary recipients and donors}

As shown in Figure 2.1, DAC members' peacebuilding ODA was concentrated in a few fragile contexts in 2018. Afghanistan was the top recipient, with USD 1.2 billion. This was almost three times the amount received by Iraq, the second-largest recipient with USD 457 million in peacebuilding ODA. Between them, Afghanistan and Iraq account for more ODA for peacebuilding than the next six largest recipients combined. Five of the top ten recipients are extremely fragile contexts: Afghanistan, Iraq, Syria, Somalia, and the Democratic Republic of the Congo. Desai (2020[49]), in a companion background paper, assesses other aspects of peace ODA including ODA for peacebuilding over time. 
Figure 2.1.Top 20 fragile recipients of peace ODA, 2018

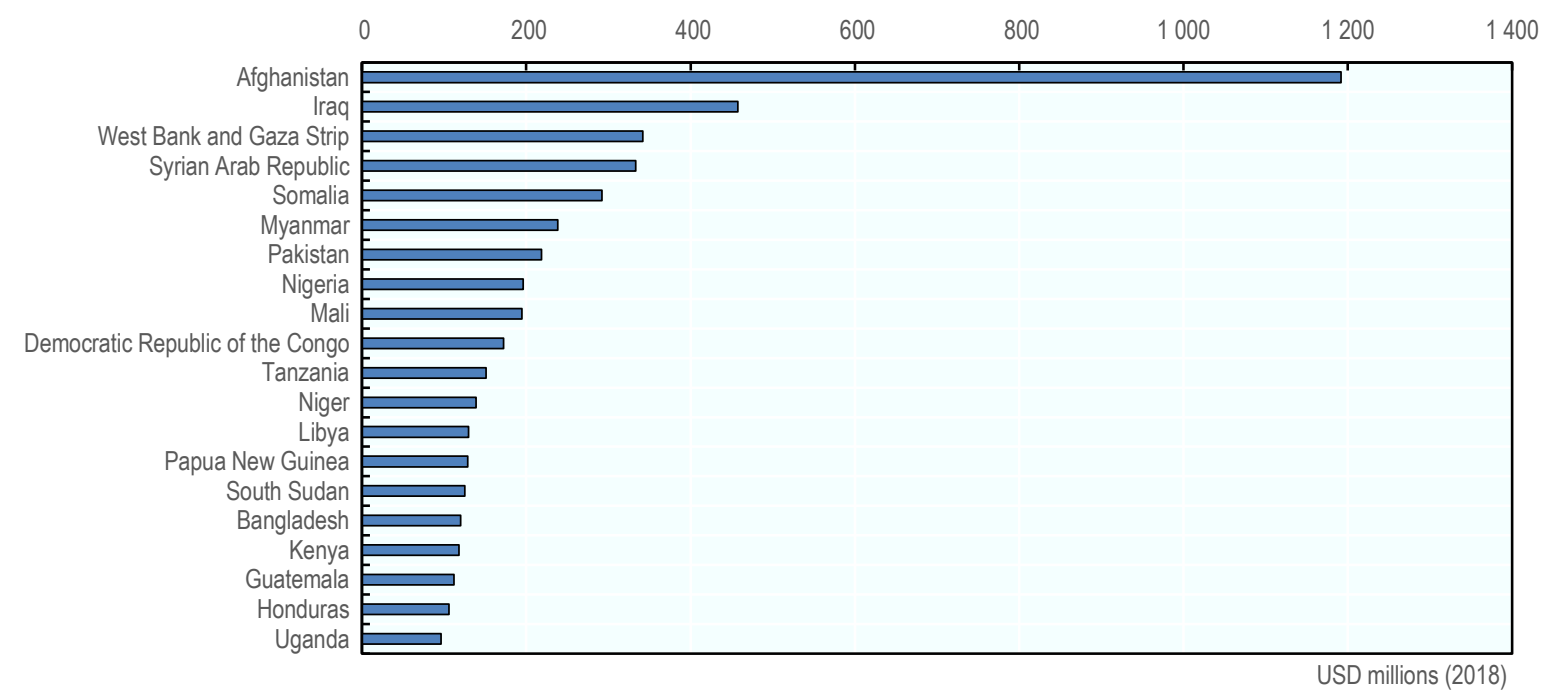

Source: OECD (2020[54]), Detailed aid statistics: ODA Official development assistance: disbursements, https://doi.org/10.1787/data-00069-en.

In 2018 , ODA to peacebuilding made up $17 \%$ of total ODA in extremely fragile contexts and $11 \%$ of total ODA in other fragile contexts. It accounted for $14 \%$ of the total in non-fragile contexts, which was three percentage points higher than in 2017 and a historical peak (Desai, 2020[49]). Since 2016, there has been little variation in the top 20 providers of peace ODA, accounting for DAC, multilateral, and non-DAC donors for which data are available in the OECD's CRS (Figure 2.2). The United States leads with USD 1.5 billion in peace ODA in 2018, followed by European Union (EU) Institutions (USD 1.2 billion), the World Bank's International Development Association (USD 1.0 billion), the United Kingdom (USD 737 million), and Germany (USD 676 million). These five donors together contributed two-thirds of peace ODA from all donors to fragile contexts in 2018. As discussed in Box 2.1, non-DAC donors are also prominent providers of ODA to fragile contexts, though not all allocate peacebuilding aid.

Figure 2.2. Top 20 providers of peace ODA among all donors, 2018

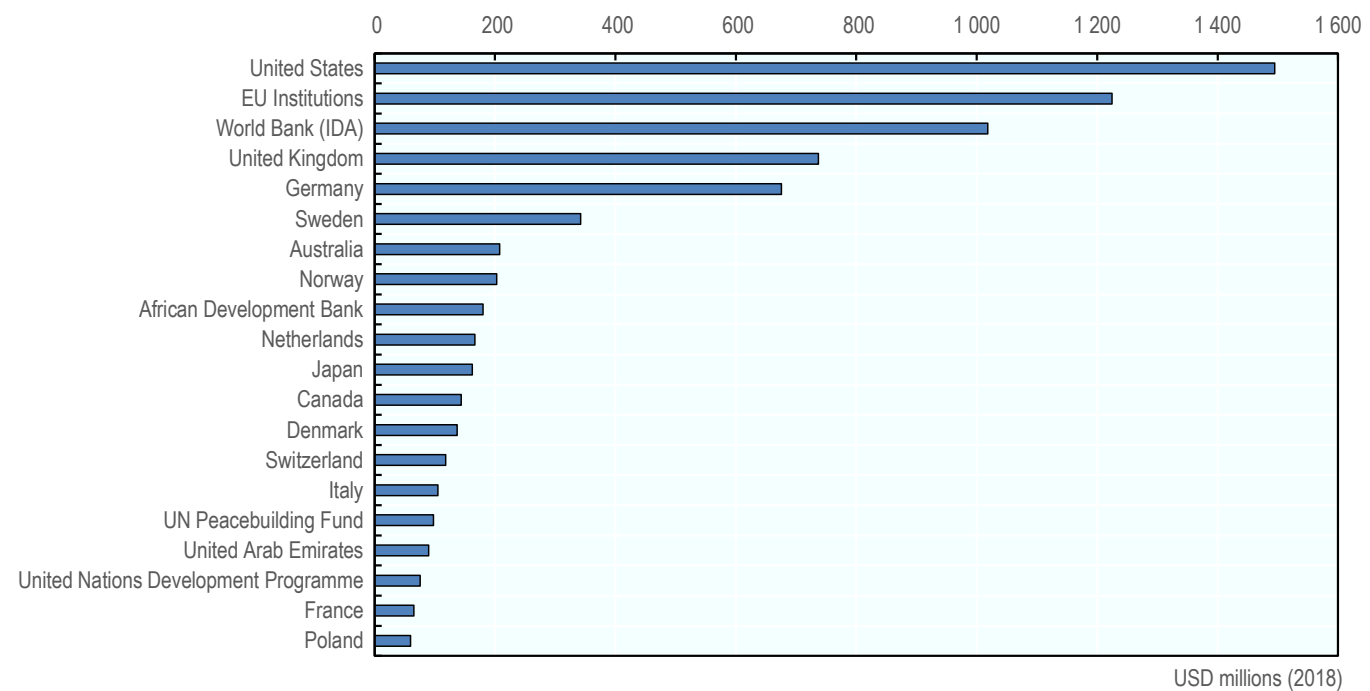

Note: IDA refers to the International Development Association.

Source: OECD (2020[54]), Detailed aid statistics: ODA Official development assistance: disbursements, https://doi.org/10.1787/data-00069-en 


\section{Box 2.1. Non-DAC countries are prominent providers of ODA to fragile contexts}

In 2018, non-DAC providers disbursed USD 14.7 billion in gross bilateral ODA to fragile contexts, $18 \%$ of the total bilateral ODA received by fragile contexts. While this was a historical peak, it is likely an underestimate of such assistance from non-DAC countries, as the Creditor Reporting System does not capture contributions from major non-DAC donors such as the People's Republic of China and India.

Almost all of the ODA from non-DAC donors for which data are available went towards the development and humanitarian pillars of the humanitarian-development-peace nexus, with only USD 175 million ( $1.2 \%$ of non-DAC ODA) targeting objectives related to peacebuilding in fragile contexts. This amount is a $60 \%$ decline over the historical peak of USD 455 million in 2017 for these objectives and, is much lower than the proportion allocated by DAC donors (13\% of total ODA in 2018$)$ towards peacebuilding in 2018.

Only 9 of the 25 non-DAC providers for which data are available in the CRS contributed towards peacebuilding in 2018. The United Arab Emirates accounted for USD 90 million or $51 \%$ of non-DAC peacebuilding ODA, followed by Saudi Arabia (USD 43 million, or 24\%) and Turkey (USD 40.7 million, or $23 \%$ ). Nearly all this ODA went to Yemen (USD 127 million, or $72.5 \%$ ) and Afghanistan (USD 28 million, or $16 \%$ ) both experiencing high-intensity armed conflict in 2019 , the most recent year for which data is available. The other recipients of non-DAC peacebuilding ODA in the top five are Somalia (USD 9 million), Pakistan (USD 4 million) and Sudan (USD 2 million).

Non-DAC peacebuilding ODA is thus concentrated in relatively few recipients and purpose codes. Almost half of this ODA went towards legal and judicial development (USD 86 million). Most of the rest of this peacebuilding ODA went to the following purpose codes $r$ : removal of land mines and explosive remnants of war (US 40 million); public sector policy and administrative management (USD 24 million); and security system management and reform (USD 21 million).

Limited evidence is available on China's contributions towards peacebuilding in fragile contexts, at least on a comparable public and systematic basis to DAC members' ODA. However, China, working to 'its own model" that prioritises diplomacy and economic support, is becoming more active in terms of peacebuilding support as a means to further its economic interests abroad (SIPRI, $2019_{[55]}$ ). China is the second-largest financial contributor to UN peacekeeping operations, accounting for $15.21 \%$ of assessed contributions to peacekeeping operations (UN, 2020[56] $)$, and is the largest contributor of peacekeeping personnel among the five permanent members of the UN Security Council. For example, China has a sizeable troop presence in UN missions including in South Sudan (UN, 2020[56]). Yet China's role as a peacebuilding actor is relatively underexplored. This may be due in part to its adherence to national ownership and non-interference in national sovereignty, both foundational principles that guide China's overseas engagement and may preclude its willingness to engage with subnational actors involved in peacebuilding (Abb, 2018[57]). Given its sizeable public diplomacy efforts in the East Asia and Pacific region and economic investments as part of the Belt and Road Initiative, China has an important role to play in global efforts for peace, stability and security (Abb, 2018[57]; Custer et al., 2017 $\left.{ }_{[58]}\right)$.

Source: OECD (2020[54), Detailed aid statistics: ODA Official development assistance: disbursements, https://doi.org/10.1787/data-00069-en. 


\section{Focus areas for peacebuilding support}

In 2018, ODA for peacebuilding totalled USD 6.1 billion, $13 \%$ of DAC members' bilateral ODA to fragile contexts and a $4 \%$ increase over 2015 (OECD, 2020[54]). The volume of peacebuilding expenditure across core government functions, inclusive political processes, and basic safety and security has been broadly consistent since 2013. These funds are usually distributed by DAC members in tandem with financial and personnel support to humanitarian, diplomacy and development activities (through multilateral and bilateral channels), as well as with other security-related activities such as peacekeeping and stabilisation. Funding streams to these areas are normally managed in independent channels that can mirror the operational gaps between actors' approaches to peacebuilding. Addressing this practice, pooled funding mechanisms that bring partners across the triple nexus together around "flexible tools that can easily be remodelled to address specific challenges" have been successfully piloted at both global and country levels (UN, 2019, p. $150_{[59]}$.Acknowledging the scope for better partnership, a recent OECD Development Co-operation Working Paper, examining the relevance of including various peace and security expenditures in the TOSSD, noted that this would offer both the opportunity to enhance dialogue between security and development actors and also the potential for greater transparency on peace and security expenditure (Bejraoui, Gaveau and Benn, 2019, pp. 9-11[60]). The classifications of peacebuilding ODA identified in this paper are drawn from States of Fragility 2018 (OECD, 2018[61]) and the Institute for Economics and Peace (2017[62]) report on the cost-effectiveness of peacebuilding, which outlines 16 purpose codes from the OECD Creditor Reporting System that together comprise peacebuilding ODA. These purpose codes aim to capture core and secondary peacebuilding activities related to basic safety and security, inclusive political processes, and core government functions (Institute for Economics and Peace, 2017[62]). Building on analysis of ODA and conflict prevention in fragile contexts (Desai, 2020[1]; Desai, 2020[49]), the OECD intends to review these purpose codes in 2021 to consider their relevance to contemporary approaches to peacebuilding.

Figure 2.3. Peacebuilding expenditures to fragile contexts, 2012-18

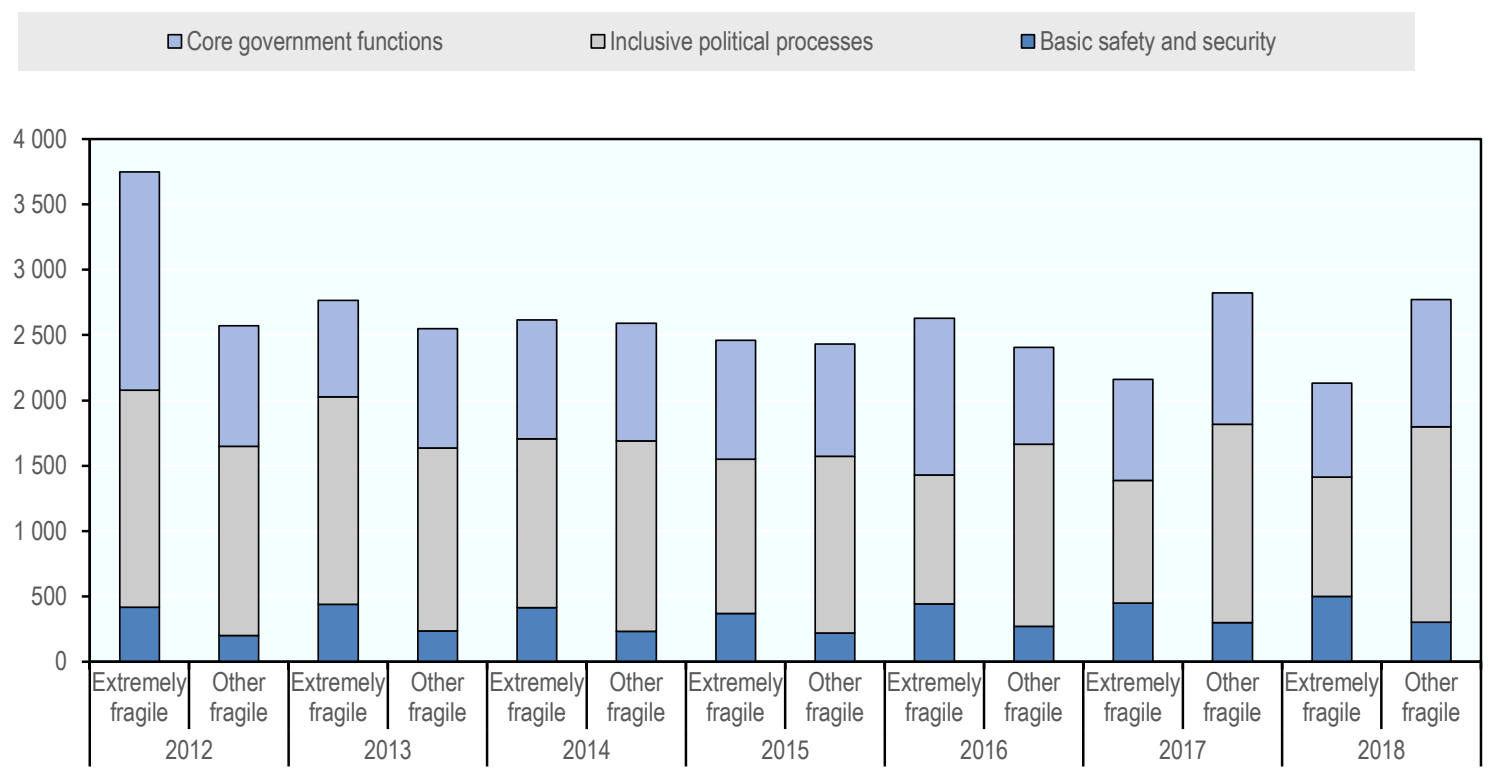

Note: <!!Add the note here. If you do not need a note, please delete this line.!!

Source: <!!Add the source here. If you do not need a source, please delete this line.!!>

Source: OECD (2020[54]), Detailed aid statistics: ODA Official development assistance: disbursements, https://doi.org/10.1787/data-00069-en. 
Whether allocated in extremely fragile or other fragile contexts, ODA for peacebuilding still amounts to a small proportion of total ODA going to fragile contexts. In both cases, the focus is on supporting core government functions and inclusive political processes. However, it is noteworthy that despite their significantly different exposure to fragility, extremely fragile and other fragile contexts receive broadly the same proportions of peace ODA. With the exception of basic safety and security - which is $3 \%$ in extremely fragile contexts versus $1 \%$ in fragile contexts - the distribution across the three main activities (core government functions, inclusive political processes, and basic safety and security) is also similar. (Figure 2.2 and Figure 2.3). ${ }^{1}$ In 2018, as in previous years (Figure 2.3) basic safety and security received the least amount of ODA, with approximately USD 800 million allocated to all fragile contexts. This category includes participation in international peacekeeping operations $-15 \%$ of financial contributions to the United Nations (UN) peacekeeping budget is considered ODA-eligible, meaning that donor countries are allowed to report a share of their financial contribution to the UN peacekeeping operations budget as multilateral ODA, irrespective of the activities conducted by the operations ${ }^{2}$ (OECD, 2017[63]). In 2018, the ODA-eligible share of DAC members' contributions to international peace operations in fragile contexts amounted to USD 550 million. However, there is a range of caveats associated with these estimates, and the extent of DAC members' contributions to international peace operations including non-ODA eligible activities are discussed more extensively in Forsberg (2020[64]).

Figure 2.4. Peacebuilding expenditure as a component of total ODA to fragile contexts, 2018

Extremely fragile
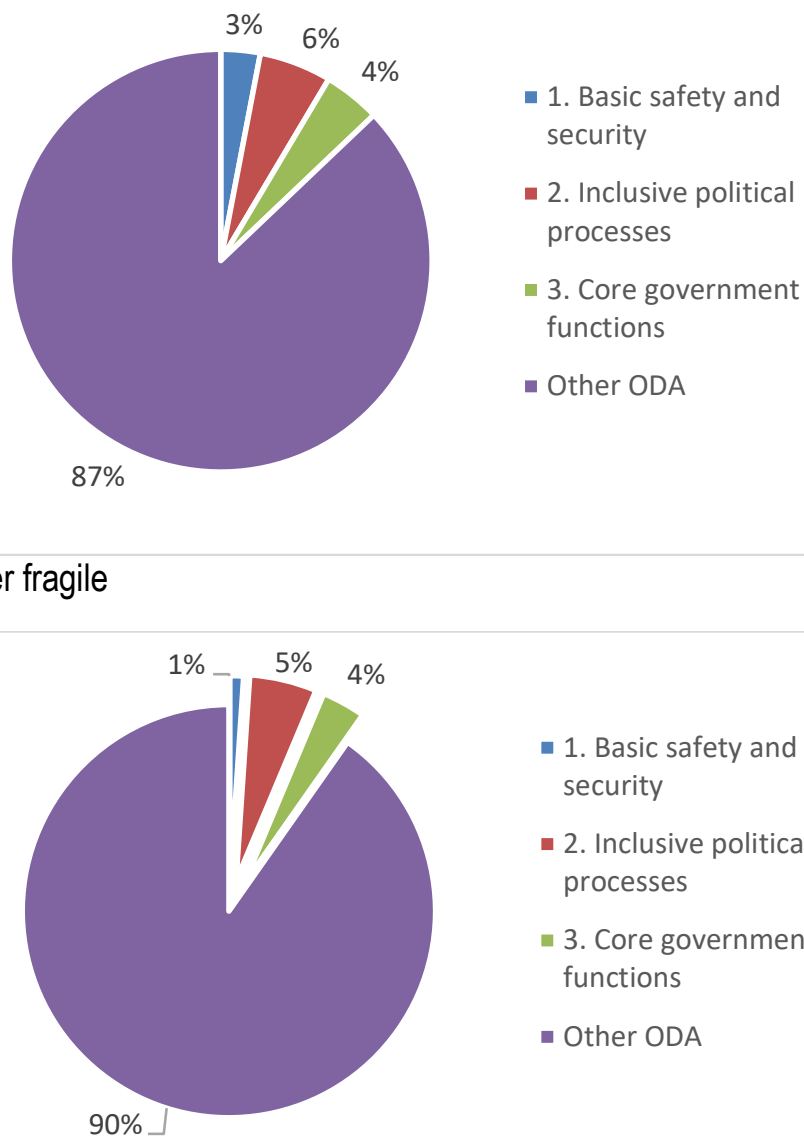

- 1. Basic safety and security

- 2. Inclusive political processes

- 3. Core government functions

- Other ODA

Source: OECD (2020[54]), Detailed aid statistics: ODA Official development assistance: disbursements, https://doi.org/10.1787/data-00069-en. 


\section{Challenges to financing peacebuilding}

The challenges of measuring peacebuilding activities, identified in 2016 and reaffirmed in 2018 by the OECD $\left(2018_{[61]}\right)$ and in 2019 by Al Maleh $\left(2019\right.$, p. 139 ${ }_{[65]}$ ), are yet to be fully addressed. ${ }^{3}$ The fragmentation of actors and approaches to peacebuilding in fragile contexts has made it increasingly difficult "to distinguish peacebuilding from state building, and from development more generally" (Institute for Economics and Peace, 2017[62]). This complexity distracts from the complementarity of funding for peace and development efforts (Buzzoni and Brinkman, 2019, pp. 141-146[66]; Wolff et al., 2020, p. 51[67]). Analysis of the CRS data shows that DAC members' ODA in 2018 reached many of the areas considered important for effective peacebuilding. However, the amounts are insufficient to realise the costeffectiveness potential of conflict prevention and peacebuilding. ${ }^{4}$ Additionally, while the CRS purpose codes capture, to a point, ODA that specifically targets peacebuilding, they will need to evolve to capture the emergence of more dynamic and flexible peacebuilding models and partnerships across the triple nexus (OECD DAC, 2019[68]).

The challenges associated with ODA for peacebuilding extend beyond questions of measurement. Recent research for Peace Direct argues that three interconnected problems affect funding for peacebuilding: an antiquated funding system, poorly structured funding and inadequate funding for local actors (Peace Direct and Kantowitz, 2020[69]). These findings correspond with the views of interviewees for this paper, who described the financing committed to peacebuilding as insufficient, unpredictable and ad hoc. ${ }^{5}$ This paper does not directly engage in a discussion of the areas raised by the Peace Direct report. However, along with the findings of Jenks and Topping $\left(2019_{[70]}\right)$, the recommendations for new approaches to local funding are a valuable contribution to the discussion.

The business case for conflict prevention and peacebuilding is generally accepted (UN/World Bank, $\left.2018_{[71]}\right)$. As is the case with conflict prevention, averting conflict through sustained, predictable and timely peacebuilding requires fewer resources than dealing with conflict once it has occurred (Desai, 2020[1]; Institute for Economics and Peace, 2017[62] $)$. The business case has not precipitated more financial and operational investment in peacebuilding for many reasons, two stand out: First, the uncertainty associated with measuring peacebuilding outcomes (Day and Caus, 2019, p. $20_{[72]}$ ), at least sufficiently to allay concerns regarding the effectiveness of peacebuilding initiatives. Second, connected to the first, a reluctance to invest in peacebuilding at the first signs of fragility.

As noted in Chapter 1, a responsive and adaptive approach to peacebuilding is important when addressing matters of state and human security that can be essential to building local confidence in a peacebuilding process. However, responding to early warning signs presents a conundrum for peacebuilding financing. Not everyone may see an urgent need to support peacebuilding initiatives, particularly in contexts that are not affected by conflict but where issues of fragility can combine to undermine stability and peace over time. Apart from traditional means of fundraising and finance, innovative options have yet to garner the necessary support or generate sufficient impact to change established approaches to peacebuilding finance (Howell and Brinkman, 2019, pp. 131-133[73]).

While the fundamentals of peacebuilding initiatives have not changed, implementation of the DAC Recommendation offers a fresh starting point from which to build partnerships to mobilise finance for effective peace practice. Aligning the analysis of fragility with the provision of ODA for peacebuilding initiatives will be an important part of making the nexus work. The implementation of new finance models will challenge existing norms across the nexus where lines of funding have been relatively constant, though arguably the impact of COVID-19, particularly on humanitarian and development finance could prove to be the disruptive event that prompts a holistic review and much-needed change. 


\section{Notes}

1 Core government functions captured by the CRS include public sector policy and administrative management, public finance management, and decentralisation and support to subnational governments. Inclusive political processes include legal and judicial development; legislatures and political parties; anticorruption organisations and institutions; democratic participation and civil society; media and free flow of information; human rights; and women's equality organisations and institutions.

2 The $15 \%$ quota is based on a survey conducted in 2017 by the OECD DAC Working Party on Development Finance Statistics, which assessed the share of activities of UN peacekeeping operations that are ODA-eligible.

3 The UN includes the codes 15180 (violence against women), 15190 (migration) and 15114 (domestic revenue mobilisation) and also has category on human rights and rule of law.

${ }^{4}$ Much research sets forth the business case for prevention, including by the New York University Center on International Cooperation and by the UN and World Bank. See for instance https://openknowledge.worldbank.org/handle/10986/28337.

5 This is from an interview with a diplomat based in Africa on 18 May 2020. 


\section{Four questions on empowering the peacebuilding agenda}

This chapter is organised around four questions that are intended to stimulate further debate on peacebuilding and fragile contexts. The answers will shape peacebuilding priorities, actions and impact over the next decade. Debates on peacebuilding have coalesced around a more or less set number of issues, particularly leading up to the publication of the United Nation (UN) Peacebuilding Architecture Review and with the publication in 2020 of the 2020-24 strategy for the UN Secretary-General's Peacebuilding Fund. As discussed in Chapters 1 and 2, there is broad consensus on approaches that emphasise cohesion, national leadership and local ownership. More and better funding is also recognised as a vital component, not just to meet existing demand as identified in the new Peacebuilding Fund strategy but also to address existing commitments such as the Women, Peace and Security Agenda that are "lagging" due to severe underfunding (UN, 2020, p. $\left.3_{[43]}\right)$. Financing is crucial as well given the potential for unknown and unforeseen environmental factors that can influence the future demand, organisational shape and practice of peacebuilding in fragile contexts. To meet these challenges, it is widely recognised that policy and programming must adopt better conflict-sensitive and risk-tolerant approaches that consider the specific needs of each context, including issues such as transition, cross-border peacebuilding and conflict prevention. This chapter looks at the environment and architecture around these issues to identify related challenges and the potential enablers of successful outcomes across these priorities.

\section{Should donors prepare for a surge in demand for peacebuilding?}

The answer is yes: a combination of push and pull factors are stressing fragility in every dimension and could lead to an unprecedented demand for peacebuilding in the short to medium term. Climate changerelated events are driving poverty, new migratory patterns and more frequent natural disasters and in certain areas, are further restricting access to resources such as water. This pattern looks set to continue (Climate Action Tracker, 2019[74]; CRED, 2020[75]). The coronavirus (COVID-19) pandemic is delivering a similar global, systemic shock, and the full extent of its socio-economic impact is slowly emerging. To varying degrees across fragile and non-fragile contexts alike, the pandemic is increasing pressures on already weak health systems (OECD, 2020, p. 32[2]) and exacerbating drivers of fragility that contribute to violent conflict and displacement, thus affecting prospects for sustaining peace (Monnier and Mayar, 2020[76]). The COVID-19 crisis also is eroding human capital in many contexts and further diminishing their ability to withstand shock (Forichon, $2020_{[77]}$ ). Though levels of armed conflict have remained relatively stable since 2015 (Chapter 1), instances of protests and violence against civilians are rising at notable levels across fragile contexts (ACLED, 2020[9]). Primarily due to the impact of the pandemic, the capacity to respond to humanitarian and peacebuilding needs, in particular, has diminished, with no guarantee of short- to medium-term recovery (Aly, 2020[78]). Without more detailed research, it cannot be assumed that there are potential causal links between diminished peace and these and other issues such as peacekeeping drawdowns (Forsberg, 2020[64]). Nonetheless, it is evident that pressure associated with the triple shock of a global pandemic, economic crises and climate change, alongside gaps in peacebuilding capacity, is rising significantly. If one accepts that these early warning signs are potentially the precursors 
of one or more crises of peace, then there is a strong argument to be made for preparing a dedicated, multinational post-pandemic conflict prevention and peacebuilding strategy. Chapters 1 and 2 demonstrate the limited impact of business-as-usual models across the humanitarian-development-peace nexus as currently practiced. A dedicated post-pandemic strategy, appropriately resourced, could ensure that sufficient capacity is generated to mitigate the worst impacts - foreseen and as yet unforeseen - of an exceptional series of global systemic shocks.

\section{How can the value of localised peacebuilding be consolidated?}

Linking the adaptive aspects of country platforms to concepts of building social cohesion could provide a pathway to harness the value of local peacebuilding for greater impact. The States of Fragility 2018 report highlighted the challenge of the "missing middle" in peacebuilding finance, where "middle-sized projects can no longer attract financing" (OECD, 2018[61]) that tends, instead, to flow to either small-scale or multimillion-dollar projects for bilateral and multilateral donors. The new UN Peacebuilding Fund strategy also recognises this as one of the key challenges of peacebuilding funding to be addressed over the 202024 cycle (UN, 2020 $\left.{ }_{[43]}\right)$. The missing middle for finance is also representative of a missing operational middle that can harness the collective potential of small-scale projects while also connecting with highlevel peacebuilding initiatives (as outlined in Chapter 1 ) to ensure that peacebuilding processes are cohesive and attuned to the needs at different levels in a fragile context.

The notion of a missing middle helps illustrate the challenge of operationally integrating localised and higher-level initiatives in peacebuilding. The question then becomes how to maintain the value of local ownership, which is critical not only to building but to sustaining peace, in the absence of structures and processes (the operational missing middle) that can harness the potential of local initiatives to advance and strengthen national and regional-level peacebuilding. In terms of operational peacebuilding missions, the "missing middle" is visible in two ways. First, localised initiatives outside of a strategic framework for peace have little chance, individually and collectively, to empower national or regional-level processes and thereby enhance sustainable peace. An example is the Civil Society Support Room for Syrian peace talks, discussed in Chapter 1, which arguably was established too late for the collective voice of peace and humanitarian actors to influence peace talks that rapidly assumed a regional and international geopolitical dynamic. Building and sustaining peace at the national level is a multidimensional process fraught with complexity and uncertainty and vulnerable to "risks of diversion, political manipulation and failure" (Rizk, $\left.2019_{[79]}\right)$. In their design, then, a peacebuilding process should identify, balance and mitigate risks; effectively engage and support leaders at all levels; and be inclusive, conflict-sensitive and sufficiently agile to respond to changing circumstances (Schreiber and Loudon, 2020[80]). Additionally, community-level ownership of peacebuilding processes can be short-lived and limited in scope and ambition, and the window for harnessing their potential can close quickly. It is also worth acknowledging that engaging local actors for peace can be a competitive process as it often occurs in a contested space where arguments for peace must contend with extremist ideologies promoted by groups that use incentives and coercion. For example, the localised forms of social protection offered by extremist groups such as Al-Shabab can be seen as an attractive alternative by communities that perceived themselves as marginalised (International Crisis Group, 2019[81]).

The second aspect of this missing middle challenge for peacebuilding is that there often is insufficient management or co-ordination capacity to organise, guide and direct local peacebuilding initiatives to ensure that they support national-level priorities for peace. In some contexts, this is highlighted in the fragmented approaches of multiple small-scale actors working independently of national processes and institutions for peace. Such fragmentation can reflect the fact that national and local governments do not have the human resources and infrastructure to co-ordinate activities for collective outcomes. It can also point to deeper issues such as deficiencies in human capital that limit the supply of suitably educated and trained people required to establish oversight and co-ordination of mid-level processes (Schreiber and 
Loudon, 2020[80]). In most contexts, only the largest bilateral and multilateral actors possess the analytical, financial and executive capacity to harness, link and empower local peacebuilding activities for a national strategy.

There are examples across the nexus of localised initiatives that have been successfully integrated into broader peace processes. For external actors in conflict-affected contexts, the organisational application of large-scale military deployments offers a template for how to link local and higher-level processes. The NATO-led missions in Afghanistan, Bosnia and Herzegovina, and Kosovo established operational (midlevel) headquarters specifically designed to link tactical actions in a context to the strategic intent at the political level. These are notably absent in UN peacekeeping operations where field headquarters report directly to UN headquarters in New York (Guéhenno and Sherman, 2009[82]). While the military application of mid-level (operational) structures and processes ${ }^{1}$ is generally seen as tried, tested and adaptable to non-military endeavours, it is also extremely expensive to maintain (both in terms of staff and analytical capability) and to adapt to locally owned approaches. An alternative and more inclusive and sustainable option is to support local and/or country platforms as a means to build oversight, co-ordination and accountability for peacebuilding over time, with the aim that the capacity created can transition into local, national or regional governance structures (Papoulidis, 2020[83]).

\section{How can the nexus work for more effective peacebuilding?}

As formal support increases for the DAC Recommendation on the Humanitarian-Development-Peace Nexus, the focus of conversation around the nexus is implementation. In one interpretation of official development assistance (ODA) support across the nexus, peacebuilding is seen as a peripheral rather the core task of actors engaged in fragile and conflict-affected contexts. As noted in Chapter 2, DAC members allocated $13 \%$ of their total bilateral ODA to fragile contexts towards peacebuilding activities in 2018 . The argument for increased funding for peacebuilding is strong (Dalrymple and Urquhart, 2020[84]). Nevertheless, current funding levels reflect uncertainty over how to connect actors, objectives and processes across the nexus for peace. The network potential that underpins the DAC Recommendation could be developed to encourage more joined-up approaches to peacebuilding, ensuring that the core competence of peacebuilders is complemented by humanitarian, development and security actors. Recognising the potential peacebuilding value of these actors will require fresh thinking on partnerships, analysis, policy delivery and evaluation.

So where can effective connections be found? In different ways, humanitarian and security actors have already established dialogue with peacebuilders that could provide the basis for further innovation. Such dialogue poses dilemmas on all sides. In a 2019 speech, Peter Maurer, president of the International Committee of the Red Cross (ICRC), said the challenge is "how to expand and uphold neutral, impartial and independent humanitarian action while designing and understanding such action as a bridge to broader and more ambitious transformative agendas" (Maurer, 2019[85]). The idea that humanitarian actions can build stability - an example cited by Maurer is the ICRC's two-track approach in Syria that includes work to repair water, sanitation and electricity infrastructure - suggests that peacebuilding trajectories or chains might be mapped through the actions of multiple actors across the nexus. This type of analysis could allow actors to collectively identify when and where to apply their particular competence to best effect. On the issue of detention, for instance, Walch (2020[86] $)$ argues that as the ICRC "does not have the capacity, or the mandate, to directly restructure or finance state institutions in charge of detention", and sees such direct actions as affecting its neutrality and impartiality, other actors with experience of working directly with or financing governments could help advance the ICRC's work to address the root causes of judicial and detention failures.

Like humanitarians, security actors can create the space for peacebuilding processes to form and develop (Forsberg, 2020[64] $)$. However, a balance must be found between the different roles (and thinking) of 
security and peacebuilding actors to keep the focus on local priorities and to ensure their respective outputs are complementary as much as possible. While peacekeeping activities make acknowledged contributions to peace, other types of peace interventions, such as stabilisation missions, can significantly complicate peacebuilding processes. There are many reasons for this, and stabilisation operations are among the most complex and difficult for any security actor to conduct. Nonetheless, the practice of stabilisation in particular can have a disruptive impact on the nexus. In contexts where security considerations (often short-term in their focus) have been allowed to take precedence over peacebuilding priorities and initiatives, peacebuilding processes can be adversely (if unintentionally) affected.

Hierarchies tend to form within and outside fragile and conflict-affected contexts and security actors' priorities can take precedence over or subsume the priorities of other actors in the nexus, distorting the logic of security activities paving the way for peace. This securitisation of approaches in the name of peace, and the power imbalance that goes with it (Green, 2016, pp. 29-31 [87]), can limit the potential contribution of other actors across the nexus. It also can affect a peacebuilding process itself, diverting "attention from the root causes of violence, and towards a focus on combating its symptoms" (Kappler, 2017[88]). Where peace and security approaches are perceived as narrowly defined or unhelpfully blurred, and where selfinterests are viewed to adversely affect policy development, the potential of the nexus will not be realised (Tronc, Grace and Nhaikian, 2019, pp. 27-29[89]). Striking a better balance between security and peacebuilding strategies is essential for building cohesion in peacebuilding across the nexus. For this to happen, two preliminary steps are necessary. First, security actors (both internal and external) should be encouraged to engage more actively in discussions on peacebuilding and the implementation of the nexus. Second, security actors themselves must consider the impact and value of their current approaches when operating alongside peacebuilding activities. In fragile contexts such as Iraq, Mali and Afghanistan, military operations in particular have blurred the boundaries with development and humanitarian activity and experimented greatly with the application of military forces in peacebuilding spaces - where the same organisation can be responsible for mentoring civil servants in a ministry of the interior and carrying out airstrikes. (Rosén, 2012, p. 39[90])

Given their ability to address fragility across dimensions, development actors can provide the leverage and incentives to both prevent conflict and chart paths from negative to positive peace outcomes (Galtung, 1969 , p. $170_{[8]}$ ). While development initiatives are frequently linked to the application of incentives or conditionality in peacebuilding processes, they are typically not designed to consider their impact on peace during their delivery. To be effective for peacebuilding, joined-up analysis should be reflected in development, humanitarian and security approaches that are aware of their peacebuilding footprint. In this regard, ideas around systems thinking for change, making the connections that matter for peace and balancing responses coherently, could provide the perspective and the framework to use the peacebuilding value-added of each actor across the triple nexus to its greatest potential. The South Sudan Health Action and Research Project in post-conflict South Sudan is an example of a developmental building block. Led by the KIT Royal Tropical Institute, the project balanced community participation and empowerment with an emphasis on aspects of human capital, linking health systems and gender (KIT Royal Tropical Institute, 2016[91]). Harnessed across the nexus, similar initiatives could have a significant peacebuilding return.

The impact of bilateral contributions to peacebuilding also needs to be considered for nexus-minded approaches to peacebuilding and the development of peacebuilding partnerships. Fragmentation is frequently identified as one of the main compromising factors for effective peacebuilding. For instance, de Conig $\left(2013_{[92]}\right)$ referred to the tragedy of the commons, whereby "each international partner, acting independently and rationally according to its own self-interest, contributes to undermining the resilience of the local government" that often has limited capacity to engage with multiple actors". The operational implications for local actors trying to balance local dynamics with layers of peacebuilding intervention are usually challenging and sometimes overwhelming.

The confusion, inefficiencies and poor results associated with fragmented peacebuilding are welldocumented (Klingebiel, Mahn and Negre, 2016, p. $69_{[93]}$ ). But fragmentation is also representative of 
competing priorities of external, national and local actors at different levels. Gambia provides an example of the multiplicity of actors that can sometimes be involved in peacebuilding. The security sector reform process in Gambia is assisted by an international advisory group that is chaired by the national security advisor and includes members from the European Union (including specialist partners), the Economic Community of West African States and the African Union and, bilaterally, from the United States and France. The group's mandate is to oversee and support the development of the Gambian national security sector according to government policy. In parallel, the government of Gambia has also engaged with China, Egypt and Turkey on aspects of defence reform, primarily associated with the training and equipping of its armed forces. Reflecting the reach of transnational corporations (Green, 2016, pp. 152-157[87]), a further layer of complexity was added when the Gambian Armed Forces reached a provisional agreement with the United States company, AGCO, with the intention of funding the army to take on commercial agricultural activities (Manneh, 2019[94]).

\section{Is it time to develop a concept of digital peacebuilding?}

The case for focused attention on the potential impact of digital platforms on peacebuilding is becoming clearer. $^{2}$ The adaptation and application of social media in fragile contexts cut across several areas of relevance for peacebuilding, including politics, society, censorship, security and economics. However, it is important to place the discussion of these issues within a wider context of Internet usage.

Social media usage in fragile contexts is growing exponentially. In 2017, Internet availability in Africa increased by more than $20 \%$, reaching more than 73 million people (Dahir, 2018[95]). The number of users more than doubled in the fragile contexts of Niger, Mozambique and Sierra Leone and increased nearly six fold in Mali, with the WhatsApp application proving most popular across the region (Dahir, 2018[95]). While this growth is significant, supply issues - in terms of both access to the Internet and access to smart mobile devices - suggest that there is substantial, untapped scope for even further growth. Research from the Pew Research Center in Washington, DC, for instance, found phone ownership in Tanzania at $13 \%$ for smartphones and $62 \%$ for basic phone service; in Kenya at $30 \%$ for smartphones and $50 \%$ for basic phone service; and in Nigeria at $32 \%$ for smartphones and $48 \%$ for basic phone service (Silver and Johnson, 2018, p. 12[96]). All of these are fragile contexts. From an access to technology perspective, there is still time for peacebuilders to consider the implications of this growth for future practice.

The positive potential of digital platforms for peacebuilding is evident. The aforementioned Pew research captured several characteristics of potential relevance to peacebuilding activities. In the countries surveyed, attitudes towards growing Internet connectivity were broadly positive, particularly in areas related to education and local economies (Silver and Johnson, 2018, p. 12[96]). Smartphone ownership was more common among younger people in sub-Saharan Africa, but could reflect disparities in terms of education and income (Silver and Johnson, 2018, pp. 14-15[96]). Greater digital access can bring risks. In one incident in Nigeria in September 2019 (to name one example), misleading and in some cases fictitious accounts of anti-immigrant violence in South Africa circulated on social media platforms, prompting attacks on South Africans in Nigeria (AFP, 2019 ${ }_{[97]}$ ). In this regard, digital platforms can be considered contested spaces for peacebuilding initiatives. While these platforms can host projects to counteract hate speech on social media (Hannington, 2018[98]) or organise social movements to tackle gender inequality (Kotsiras, 2020 , p. 14[99]), they also can be used to ruthlessly exploit vulnerability, fear, information vacuums, and marginalised or isolated communities. For example, in 2014, the so-called Islamic State group, or ISIS, carried out a sustained social media campaign to terrorise an Iraqi garrison of 25000 military personnel into fleeing Mosul, a city of 1.8 million inhabitants, allowing just 1500 ISIS fighters to take control of the city virtually unopposed (Brooking and Singer, 2016 $[100])$.

These are comparatively localised examples of the instrumentalisation of digital technologies. But recent research shows the broader potential of digital technologies to have sustained and strategic impact on 
peacebuilding processes. Peacebuilders must now contend with the reality of filter bubbles in which, through a process and combination of algorithms and self-selection, Internet users are only exposed to a narrow range of news and opinion (Kotsiras, 2020, p. 52[99]) that exploits mistrust and polarises public opinion for political ends. One example, highlighted by Mozur $\left(2018_{[101]}\right)$ and others, is the Myanmar military's systematic targeting of the country's mostly Muslim Rohingya minority group using social media platforms such as Facebook. The big data aspects of digital technology can undoubtedly enable better analysis of factors affecting peace enabling early warning and swifter decision making for peacebuilding objectives. Understanding the intersection between the local and global aspects of digital spaces will form an important part of future peacebuilding (Dwyer and Molony, 2019 $\left.{ }_{[102]}\right)$. In this regard, perceptions of the authenticity of peacebuilding motives will matter where mass communication is conducted through digital platforms and where peacebuilders must ensure that social cohesion and local ownership continue to inform their digital interactions.

These developments are also significant for how peacebuilders perceive and engage with mass movements. For example recent research on non-violent movements in peace processes and political transitions has pointed to movements' use of digital activism to inform and mobilise populations on issues such as online education campaigns on effective responses to the COVID-19 in Sudan (Stephan, 2019, p. $\left.3_{[103]}\right)$. On more contentious issues, the use of digital technology by mass movements is changing the character of established peacebuilding challenges. Difficulties associated with the reluctance of parties to accept mediation are complicated by the use of encrypted and open platforms to shape a movement's opinions or actions. Similarly, interactions with decentralised and leaderless movements are likely to require responses that can engage to some extent with their preferred (digital) means of communication. As noted above, the disruptive potential of digital means is already being used in fragile and conflict affected contexts, the adaptation of such means by mass movements is also deserving of more research (Stephan, 2019, pp. 6-9[103]).

\section{Notes}

${ }^{1}$ NATO uses the Comprehensive Operations Planning Directive (COP-D). See https://www.act.nato.int/images/stories/events/2016/sfpdpe/copd v20.pdf.

2 Examples of more focused research on digital platforms and peacebuilding include, for example, the Kotsiras (2020[99]) report for Peace Direct entitled Digital Pathways for Peace: Insights and Lessons from a Global Online Consultation at https://www.peacedirect.org/wp-content/uploads/2020/08/PD-LVP-TechReport.pdf. Also see Social Media and Politics in Africa: Democracy, Censorship and Security, edited by Dwyer and Molony (2019 [102]), at https://www.zedbooks.net/shop/book/social-media-and-politics-in-africal. 


\section{Annex A. Methodology}

\section{Definitions of violence and conflict}

Violence comprises a broad range of actions including, among others, sexual and gender-based violence, terrorism, armed conflict, and homicides. Categorisations of violence and violent deaths also vary and may differ based on norms, culture, or definition in national and international law (Asylbek kyzy, Delgado and Milante, 2020[107]). The Global Registry of Violent Deaths categorises violent deaths in 16 different categories; intentional and unintentional homicides, killings in legal interventions, and direct conflict cause the largest numbers of deaths (Asylbek kyzy, Delgado and Milante, 2020[107]). The primary focus in States of Fragility 2020 is on violence in violent conflict, but with the recognition that all forms of violence contribute to fragility across multiple dimensions.

Violent conflict in States of Fragility 2020 refers to all state-based (both intrastate and inter-state) and non-state conflicts. A state-based conflict (also referred to as armed conflict) is understood in this publication to be "a contested incompatibility that concerns government or territory or both where the use of armed force between two parties results in at least 25 battle-related deaths. Of these two parties, at least one is the government of a state" (Gleditsch et al., 2002[106]). A high-intensity conflict is a conflict that reaches the intensity of war, resulting in at least 1000 battle-related deaths. These definitions are in accordance with the Uppsala Conflict Data Program (UCDP) definitions. A non-state conflict refers to "the use of armed force between two organized armed groups, neither of which is the government of a state, which results in at least 25 battle-related deaths in a year" in accordance with the UCDP definition (Sundberg, Eck and Kreutz, 2012[104]). Conflict-affected contexts are contexts in which there was at least one active armed conflict in 2019. States of Fragility 2020 also makes reference to one-sided violence, defined by UCDP as the "the use of armed force by the government of a state or by a formally organized group against civilians which results in at least 25 deaths in a year" (Eck and Hultman, $2007_{[105]}$ ).

\section{References}

Abb, P. (2018), "China's emergence as a peacebuilding actor: From 'peaceful development' to 'developmental peace'?", The Asia Dialogue, https://theasiadialogue.com/2018/12/24/chinasemergence-as-a-peacebuilding-actor-from-peaceful-development-to-developmental-peace/.

ACLED (2020), ACLED Dashboard (database), Armed Conflict Location \& Event Data Project (ACLED), Madison, WI, https://www.acleddata.com/dashboard/\#/dashboard (accessed on 21 August 2020).

Advisory Group of Experts (2015), The Challenge of Sustaining Peace: Report of the Advisory Group of Experts for the 2015 review of the United Nations Peacebuilding Architecture, United Nations, New York, https://www.un.org/pga/wpcontent/uploads/sites/3/2015/07/300615 The-Challenge-of-Sustaining-Peace.pdf. 
AFP (2019), Misleading social media posts fuel tensions over xenophobic violence gripping SA, https://www.news24.com/news24/southafrica/news/misleading-social-media-posts-fueltensions-over-xenophobic-violence-gripping-sa-20190905.

African Union (2018), Guidelines Note for the Implementation of the African Union Post-Conflict Reconstruction and Development Policy, https://www.peaceau.org/uploads/final-guidelinesnote.pdf.

Al Maleh, A. (2019), "Official development assistance and peacebuilding: Ten-year trends", in Financing the UN Development System 2019: Time for Hard Choices, United Nations MultiPartner Trust Fund Office, New York/Dag Hammarskjöld Foundation, Uppsala, Sweden, https://www.daghammarskjold.se/wp-content/uploads/2019/09/financial-instr-report-2019interactive.pdf.

Alliance for Peacebuilding (n.d.), What is Peacebuilding? (webpage), https://www.allianceforpeacebuilding.org/about-peacebuilding (accessed on 28 August 2020).

Aly, H. (2020), This global pandemic could transform humanitarianism forever. Here's how, https://www.thenewhumanitarian.org/analysis/2020/06/08/coronavirus-transformhumanitarianism-aid (accessed on 31 August 2020).

Asylbek kyzy, G., C. Delgado and G. Milante (2020), Gaps Report: Challenges of Counting All Violent Deaths Worldwide, Global Registry of Violent Deaths - GReVD, https://grevd.org/images/uploads/resources/GReVD GAPS RPT FINAL.pdf.

Ball, N. (2014), "Lessons from Burundi's security sector reform process", Africa Security Brief, No. 29, Africa Center for Strategic Studies, Washington, DC, https://africacenter.org/publication/lessons-from-burundis-security-sector-reform-process/.

Bejraoui, A., V. Gaveau and J. Benn (2019), "TOSSD - Tracking peace and security expenditures in support of the SDGs", OECD Development Co-operation Working Papers, No. 66, OECD Publishing, Paris, https://dx.doi.org/10.1787/02e67566-en.

Bojicic-Dzelilovic, V. and M. Martin (2016), Local Ownership Challenges in Peacebuilding and Conflict Prevention, Global Partnership for the Prevention of Armed Conflict, The Hague, https://www.gppac.net/files/201812/D4.7 Best\%20Practices\%20Report\%20Local\%200wnership final PU.pdf.

Brooking, E. and P. Singer (2016), War goes viral: How social media is being weaponized across the world, https://www.theatlantic.com/magazine/archive/2016/11/war-goes-viral/501125/.

Buzzoni, L. and H. Brinkman (2019), "How the Peacebuilding Fund is investing in the [66] Sustainable Development Goals", in Financing the UN Development System: Time for Hard Choices, United Nations Multi-Partner Trust Fund Office, New York/Dag Hammarskjöld Foundation, Uppsala, Sweden, https://www.daghammarskjold.se/wpcontent/uploads/2019/09/financial-instr-report-2019-interactive.pdf.

Campbell, S. (2018), "Global governance and local peace", in Global Governance and Local Peace: Accountability and Performance in International Peacebuilding, Cambridge University Press, http://dx.doi.org/10.1017/9781108290630. 
Castillejo, C. (2016), Political Parties and Peacebuilding, Norwegian Peacebuilding Resource Centre, Oslo, https://reliefweb.int/sites/reliefweb.int/files/resources/a3a0e081d8d2852cc065394acc740420. pdf.

Cheng, C., J. Goodhand and P. Meehan (2018), Synthesis Paper: Securing and Sustaining Elite Bargains that Reduce Violent Conflict, Stabilisation Unit, Government of the United Kingdom, London, https://assets.publishing.service.gov.uk/government/uploads/system/uploads/attachment dat a/file/765882/Elite Bargains and Political Deals Project - Synthesis Paper.pdf.

Climate Action Tracker (2019), Warming Projections Global Update, http://AT (2019), Climate Action Tracker: Warming Projections Global Update, https://climateactiontracker.org/documents/698/CAT 2019-1210 BriefingCOP25 WarmingProjectionsGlobalUpdate Dec2019.pdf.

Collins, A. and C. Thiessen (2019), "A grounded theory of local ownership as meta-conflict in Afghanistan", Cooperation and Conflict, Vol. 55/2, pp. 216-234, http://dx.doi.org/10.1177/0010836719895040.

CRED (2020), EM-DAT - The International Disaster Database, Centre for Research on the Epidemiology of Disasters (CRED), UC Louvain, Brussels, https://public.emdat.be/.

Custer, S. et al. (2017), Beyond the Tyranny of Averages: Development Progress from the Bottom Up, AidData at William \& Mary, Williamsburg, VA, https://www.aiddata.org/publications/beyond-the-tyranny-of-averages-development-progressfrom-the-bottom-up.

Dahir, A. (2018), "This is the most popular messaging app in Africa", World Economic Forum, https://www.weforum.org/agenda/2018/02/why-whatsapp-is-the-most-popular-messagingapp-in-africal.

Dalrymple, S. and A. Urquhart (2020), "Peace in the triple nexus: what challenges do donors face?", Development Initiatives blog, https://devinit.org/blog/peace-triple-nexus-whatchallenges-do-donors-face/ (accessed on 31 August 2020).

Day, A. and J. Caus (2019), Conflict Prevention in the Sahel: Emerging Practice Across the UN, Centre for Policy Research, United Nations University, New York, https://i.unu.edu/media/cpr.unu.edu/post/3640/UNU Conflict Prevention FINAL WEB.pdf.

DCAF (2020), Principles in Practice: Political Engagement (webpage), DCAF - Geneva Centre for Security Sector Governance, https://issat.dcaf.ch/Learn/SSR-in-Practice/Principles-inPractice/Political-Engagement.

DCAF (2019), Country Profiles: Zimbabwe SSR Background Note, DCAF - Geneva Centre for Security Sector Governance, https://issat.dcaf.ch/Learn/Resource-Library/CountryProfiles/Zimbabwe-SSR-Background-Note (accessed on 28 August 2020).

de Coning, C. (2018), "Adaptive peacebuilding", International Affairs, Vol. 94/2, pp. 301-317, https://doi.org/10.1093/ia/iix251.

de Coning, C. (2013), "Complexity theory and the local in peacebuilding", Peace Insight blog, https://www.peaceinsight.org/blog/2013/06/complexity-theory-and-the-local-in-peacebuilding/. 
de Coning, C. (2013), "Understanding peacebuilding as essentially local”, Stability: International Journal of Security and Development, Vol. 2/1, pp. 1-6, http://dx.doi.org/10.5334/sta.as.

de Coning, C. and L. Gelot (2020), "Placing people at the center of UN peace operations", IPI Global Observatory, https://theglobalobservatory.org/2020/05/placing-people-center-unpeace-operations/\#more-20380 (accessed on 26 June 2020).

Desai, H. (2020), “Conflict prevention in fragile contexts", OECD Publishing, Paris.

Desai, H. (2020), "States of Fragility and official development assistance", OECD Publishing, Paris.

Dwyer, M. and T. Molony (eds.) (2019), Social Media and Politics in Africa: Democracy, Censorship and Security, Zed Books, https://www.zedbooks.net/shop/book/social-media-andpolitics-in-africal.

Eaton, T. et al. (2019), Conflict Economies in the Middle East and North Africa, Chatham House, London, https://www.chathamhouse.org/sites/default/files/2019-08-13-ConflictEconomies.pdf.

Eck, K. and L. Hultman (2007), "One-sided violence against civilians in war", Journal of Peace Research, Vol. 44/2, pp. 233-246, http://dx.doi.org/10.1177/0022343307075124.

Forichon, K. (2020), "Considering human capital in a multidimensional analysis of fragility", OECD Publishing, Paris.

Forsberg, E. (2020), "Security actors in fragile contexts", OECD Publishing, Paris.

Forsberg, E. and J. Marley (2020), "Diplomacy and peace in fragile contexts", OECD Publishing, Paris.

Galtung, J. (1969), "Violence, peace and peace research", Journal of Peace Research, Vol. 6/3, pp. 167-191, http://www.jstor.org/stable/422690.

Gleditsch, N. et al. (2002), "Armed conflict 1946-2001: A new dataset", Journal of Peace Research, Vol. 39/5, pp. 615-637, https://doi.org/10.1177/0022343302039005007.

Graff, C. and L. Bailey (2020), Conflict Prevention in the COVID Era: Why the U.S. Cannot Afford to Go it Alone, United States Institute of Peace, Washington, DC, https://www.usip.org/publications/2020/08/conflict-prevention-covid-era-why-us-cannot-affordgo-it-alone (accessed on 29 August 2020).

Green, D. (2016), How Change Happens, Oxford University Press, https://library.oapen.org/bitstream/id/a2d96f5a-5189-4cf8-a876-d44eda71545f/618650.pdf.

Gruener, S., S. Smith and M. Hald (eds.) (2019), External support for internal dialogue, https://www.daghammarskjold.se/wp-content/uploads/2019/10/dd64-dialogue-web1.pdf.

Guéhenno, J. and J. Sherman (2009), Command and Control Arrangements in United Nations Peacekeeping Operations, International Forum for the Challenges of Peace Operations, Stockholm, http://www.operationspaix.net/DATA/DOCUMENT/4998 v Command and Control Arrange ments in United Nations Peacekeeping Operations.pdf. 
Hammergreen, L. (1998), Political Will, Constituency Building, and Public Support in Rule of Law Programs, United States Agency for International Development, Washington, DC, https://issat.dcaf.ch/download/2200/19056/Hammergren\%20Political\%20Will.pdf.

Hannington, O. (2018), "An IT campaign to tackle hate speech and build peace online", Peace Insight blog, https://www.peaceinsight.org/blog/2018/06/new-it-campaign-battles-hatespeech-online/ (accessed on 3 September 2020).

Hellmüller, S. and M. Zahar (2019), "UN-led mediation in Syria and civil society", Accord 28, pp. 84-87, https://rc-services-assets.s3.eu-west-1.amazonaws.com/s3fspublic/Navigating inclusion in peace processes Accord Issue 28.pdf.

Hendrickson, D. (2014), The Burundi Defence Review: Lessons Identified, Department of War Studies, King's College, London, https://issat.dcaf.ch/download/62427/1033023/Burundi\%20lesson\%20learned\%20report Fina \%20ENGLISH1.pdf.

Howell, C. and H. Brinkman (2019), "Innovative finance for peacebuilding: It is time to invest", in Financing the UN Development System: Time for Hard Choices, United Nations Multi-Partner Trust Fund Office, New York/Dag Hammarskjöld Foundation, Uppsala, Sweden, https://acuns.org/wp-content/uploads/2019/09/financial-instr-report-2019-interactive-1.pdf.

Human Rights Watch (2020), Zimbabwe: SADC, AU should denounce crackdown, https://www.hrw.org/news/2020/08/06/zimbabwe-sadc-au-should-denounce-crackdown (accessed on 28 August 2020).

Institute for Economics and Peace (2020), Global Peace Index 2020: Measuring Peace in a Complex World, http://visionofhumanity.org/app/uploads/2020/06/GPI 2020 web.pdf.

Institute for Economics and Peace (2017), Measuring Peacebuilding Cost-effectiveness, http://visionofhumanity.org/app/uploads/2017/03/Measuring-Peacebuilding WEB.pdf.

International Crisis Group (2019), "Women and Al-Shabaab's insurgency”, Africa Briefing, No. 145, https://d2071andvip0wj.cloudfront.net/b145-women-and-al-shabaab 0.pdf (accessed on 8 July 2020).

International Institute for Strategic Studies (2019), The Armed Conflict Survey 2019, https://www.iiss.org/publications/armed-conflict-survey/2019/armed-conflict-survey2019/armed-conflict-and-forced-displacement.

Jenks, B. and J. Topping (2019), Financing the UN Development System: Time for Hard Choices, United Nations Multi-Partner Trust Fund Office, New York/Dag Hammarskjöld Foundation, Uppsala, Sweden, https://acuns.org/wp-content/uploads/2019/09/financial-instrreport-2019-interactive-1.pdf.

Kappler, S. (2017), "The securitization of international peacebuilding", in Securitization in Statebuilding and Intervention, Nomos, Baden-Baden, Germany, http://dro.dur.ac.uk/20248/1/20248.pdf?DDD35+qjhf12+d700tmt.

KIT Royal Tropical Institute (2016), South Sudan Health Action and Research Project (SHARP), https://www.kit.nl/project/south-sudan-health-action-and-research-project-sharp/ (accessed on 3 September 2020). 
Klingebiel, S., T. Mahn and M. Negre (eds.) (2016), The Fragmentation of Aid: Concepts, Measurements and Implications for Development Cooperation, Palgrave Macmillan UK, http://dx.doi.org/10.1057/978-1-137-55357-7.

Kotsiras, D. (2020), Digital Pathways for Peace: Insights and Lessons from a Global Online Consultation, Peace Direct, London, https://www.peacedirect.org/wpcontent/uploads/2020/08/PD-LVP-Tech-Report.pdf.

Manneh, K. (2019), "Army defends $\$ 125$ million commercial agric [roject, says it'll create employment", The Cronicle, https://www.chronicle.gm/army-defends-125-million-commercialagric-project-says-itll-create-employment/.

Maurer, P. (2019), "The contribution of humanitarian action to peace", International Committee of the Red Cross, https://www.icrc.org/en/document/where-humantiarian-action-meets-peacebuilding (accessed on 1 September 2020).

Monnier, C. and H. Mayar (2020), “Making sure peace isn't a casualty of COVID-19 in fragile states", World Politics Review, https://www.worldpoliticsreview.com/articles/28734/makingsure-peace-isn-t-a-casualty-of-covid-19-in-fragile-states.

Mozur, P. (2018), A Genocide Incited on Facebook, with Posts from Myanmar's Military, https://www.nytimes.com/2018/10/15/technology/myanmar-facebook-genocide.html.

Mukeredzi, T. (2020), Zimbabwe's triple threat: Coronavirus, food shortages, and an economy in meltdown, https://www.thenewhumanitarian.org/news/2020/04/09/zimbabwe-coronavirusfood-economy (accessed on 28 August 2020).

Nantulya, P. (2019), Burundi, the Forgotten Crisis, Still Burns, African Center for Strategic Studies, Washington, DC, https://africacenter.org/spotlight/burundi-the-forgotten-crisis-stillburns/.

OECD (2020), "Detailed aid statistics: ODA Official development assistance: disbursements", OECD International Development Statistics (database), https://dx.doi.org/10.1787/data00069-en (accessed on 28 September 2020).

OECD (2020), "Mission drawdowns: Financing a sustainable peace: Sustaining gains and supporting economic stability post UN mission withdrawal", OECD Development Policy Papers, No. 28, OECD Publishing, Paris, https://dx.doi.org/10.1787/a0b4c681-en.

OECD (2020), States of Fragility 2020, OECD Publishing, Paris, https://dx.doi.org/10.1787/ba7c22e7-en.

OECD (2018), States of Fragility 2018, OECD Publishing, Paris, https://dx.doi.org/10.1787/9789264302075-en.

OECD (2017), "DAC Working Party on Development Finance Statistics: Technical review of the ODA coefficient for United Nations peacekeeping operations", OECD Publishing, Paris.

OECD (2017), "ODA Casebook on Conflict, Peace and Security Activities", OECD Publishing, Paris, https://one.oecd.org/document/DCD/DAC(2017)22/FINAL/en/pdf.

OECD (2016), States of Fragility 2016: Understanding Violence, OECD Publishing, Paris, https://dx.doi.org/10.1787/9789264267213-en. 
OECD DAC (2019), DAC Recommendation on the Humanitarian-Development-Peace Nexus, OECD Publishing, Paris, https://legalinstruments.oecd.org/en/instruments/OECD-LEGAL$\underline{5019}$.

Papoulidis, J. (2020), Country Platforms in Fragile States: A New Path for Development Cooperation, Global Delivery Initiative, http://www.globaldeliveryinitiative.org/blogs/countryplatforms-fragile-states-new-path-development-cooperation.

Papoulidis, J. (2020), Country Platforms in Fragile States: A New Path for Development Cooperation, http://www.globaldeliveryinitiative.org/blogs/country-platforms-fragile-statesnew-path-development-cooperation.

Peace Direct and R. Kantowitz (2020), Radical Flexibility: Strategic Funding for the Age of Local Activism, https://www.peaceinsight.org/reports/peacefund/.

Pelizzo, R. and R. Stapenhurst (2014), "Oversight effectiveness and political will: Some lessons from West Africa", The Journal of Legislative Studies, Vol. 20/2, pp. 255-261, https://doi.org/10.1080/13572334.2013.829277.

Pettersson, T. and M. Öberg (2020), “Organized violence, 1989-2019”, Journal of Peace Research, Vol. 57/4, https://journals.sagepub.com/doi/pdf/10.1177/0022343320934986.

Rosén, F. (2012), "Third-Generation Civil-Military Relations. Moving Beyond the SecurityDevelopment Nexus", PRISM, Vol. 2/1, https://cco.ndu.edu/Portals/96/Documents/prism/prism 2-1/Prism 27-42 Rosen.pdf.

Rotmann, P. (2019), Men with Guns: Political Economy Lessons for Disbanding or Integrating Hybrid Security Forces, https://www.gppi.net/2019/09/12/men-with-guns-political-economylessons-for-disbanding-or-integrating-hybrid-security-forces.

Schreiber, D. and S. Loudon (2020), Fit for Fragility, OECD Publishing, Paris.

Semple, M. (2019), "Internationalisation and inclusiveness in Afghan peace processes", Accord 28, pp. 88-96, https://rc-services-assets.s3.eu-west-1.amazonaws.com/s3fspublic/Navigating inclusion in peace processes Accord Issue 28.pdf.

Silver, L. and C. Johnson (2018), Internet Connectivity Seen as Having Positive Impact on Life in Sub-Saharan Africa: But Digital Divides Persist, Pew Research Center, Washington, DC, https://www.pewresearch.org/global/2018/10/09/internet-connectivity-seen-as-havingpositive-impact-on-life-in-sub-saharan-africal.

SIPRI (2020), SIPRI Yearbook: : Armaments, Disarmament and International Security, Stockholm International Peace Research Institute (SIPRI), https://www.sipri.org/sites/default/files/2020-06/yb20 summary en v2.pdf.

SIPRI (2019), "China's rising role in sustainable development and peacebuilding contexts", Stockholm Forum on Peace and Development 2019, https://www.sipri.org/sites/default/files/Session\%2034 SthlmForum\%202019.pdf (accessed on 3 September 2020).

Slim, H. (2020), "People power in humanitarian action", ICRC Humanitarian Law \& Policy blog, https://blogs.icrc.org/law-and-policy/2020/02/20/people-power-humanitarian-action/ (accessed on 28 August 2020). 
Stephan, M. (2019), Mediating mass movements, https://www.hdcentre.org/wp-

[103] content/uploads/2020/09/Mediating-Mass-Movements.pdf.

Sundberg, R., K. Eck and J. Kreutz (2012), "Introducing the UCDP Non-State Conflict Dataset", Journal of Peace Research, Vol. 49/2, pp. 351-362, http://dx.doi.org/10.1177/0022343311431598.

Travers, P. (2015), Peacebuilding and Political Accompaniment, United Nations University Centre for Policy Research, New York, https://collections.unu.edu/eserv/UNU:3222/unu cpr peacebuilding accompaniment.pdf.

Tronc, E., R. Grace and A. Nhaikian (2019), Realities and Myths of the "Triple Nexus": Local Perspectives on Peacebuilding, Development, and Humanitarian Action in Mali, Harvard Humanitarian Initiative, Cambridge, MA, https://reliefweb.int/sites/reliefweb.int/files/resources/SSRN-id3404351 0.pdf (accessed on 9 July 2020).

UCDP (2020), Uppsala Conflict Data Program - Afghanistan (database), https://ucdp.uu.se/country/700.

UCDP (2020), Uppsala Conflict Data Program (database), https://ucdp.uu.se/.

UN (2020), "Peacebuilding Fund: Report of the Secretary-General", United Nations General Assembly, New York, https://reliefweb.int/sites/reliefweb.int/files/resources/sg report 2019.pdf.

UN (2020), Secretary-General's Peacebuilding Fund, 2020-2024 Strategy, United Nations), New York, https://www.un.org/peacebuilding/sites/www.un.org.peacebuilding/files/documents/pbf strate gy 2020-2024 final.pdf.

UN (2020), United Nations Peacekeeping - China (webpage), https://peacekeeping.un.org/en/china.

UN (2020), United Nations Peacekeeping - Terminology (webpage), https://peacekeeping.un.org/en/terminology (accessed on 28 August 2020).

UN (2020), United Nations Peacekeeping: How we are funded (webpage), https://peacekeeping.un.org/en/how-we-are-funded (accessed on 3 September 2020).

UN (2019), "Financing the humanitarian-development-peace nexus", in Financing the UN Development System: Time for Hard Choices, United Nations Multi-Partner Trust Fund Office, New York/Dag Hammarskjöld Foundation, Uppsala, Sweden, https://acuns.org/wpcontent/uploads/2019/09/financial-instr-report-2019-interactive-1.pdf.

UN (2019), Peacebuilding: Countries Declared Eligible to the PBF by the Secretary-General (webpage), United Nations, New York, https://www.un.org/peacebuilding/content/list-pbfcountries-declared-eligible (accessed on 31 August 2020).

UN (2018), Report of the Secretary-General: Peacebuilding and sustaining peace, United Nations Security Council, New York, https://undocs.org/en/A/72/707. 
UN Peacebuilding (2019), PBF Project Progress Report - Solomon Islands, https://info.undp.org/docs/pdc/Documents/SLB/YEPproject\%20PBF-SLB-H1\%20progress $\% 20$ report $\% 20 \% 20-\% 202019 \% 20$ ENGLISH final.pdf.

UN Peacebuilding (2018), PBF Project Document - Solomon Islands, https://info.undp.org/docs/pdc/Documents/SLB/181128 Solomon\%20lslands\%20PRF\%20Yo uth\%20project ProDoc.pdf.

UN Peacebuilding Fund (2019), Building Peace in the Sahel, https://unpeacebuildingfund.exposure.co/building-peace-in-the-sahel (accessed on 29 August 2020).

UN Peacebuilding Fund (2018), Central African Republic Visit Report: Delivering Peace Dividends in a Dire Humanitarian Context, https://unpeacebuildingfund.exposure.co/delivering-peace-dividends.

UN/World Bank (2018), Pathways for Peace: Inclusive Approaches to Preventing Violent Conflict, World Bank, Washington, DC, https://openknowledge.worldbank.org/handle/10986/28337.

UNDP (2020), Strengthening Social Cohesion: Conceptual Framing and Programming Implications, United Nations Development Programme, New York, https://www.undp.org/content/dam/undp/library/km-qap/undp-cb social cohesion guidance-conceptual framing and programming.pdf.

Vernon, P. (2019), Local Peacebuilding: What Works and Why?, Peace Direct, London/Alliance for Peacebuilding, Washington, DC, https://peaceinsight-whatworks.s3.eu-central1.amazonaws.com/pd-local-peacebuilding-report-v2.pdf.

Walch, C. (2020), "Deprived of freedom: How detainees in conflict zones could benefit from a 'triple nexus' approach", ICRC Humanitarian Law \& Policy blog, https://blogs.icrc.org/law-andpolicy/2020/07/09/detainees-triple-nexus/ (accessed on 2 September 2020).

Wolff, J. et al. (2020), Peace and Development 2020: An Analysis of Recent Experiences and Findings, Peace Research Institute Frankfurt, https://www.hsfk.de/fileadmin/HSFK/hsfk downloads/Peace and Development2020.pdf.

World Bank (2020), The World Bank in Zimbabwe (webpage), https://www.worldbank.org/en/country/zimbabwe/overview. 


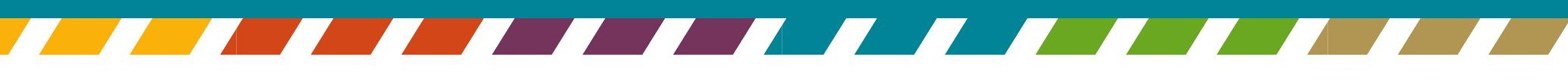

